TECTONICS, VOL. 13, NO. 5, PAGES 1161-1182, OCTOBER 1994

\title{
Tertiary metamorphic core complexes in Sonora, northwestern Mexico
}

\author{
Jonathan A. Nourse \\ Department of Geological Sciences, California State Polytechnic University, Pomona
}

Thomas H. Anderson

Department of Geology and Planetary Sciences, University of Pittsburgh, Pennsylvania

\author{
Leon T. Silver \\ Division of Earth and Planetary Sciences, California Institute of Technology, Pasadena
}

\begin{abstract}
Several ranges encompassing more than 35,000 $\mathrm{km}^{2}$ of Sonora, Mexico, contain distinctly lineated and foliated granitic and metamorphic rocks that constitute the lower plates of metamorphic core complexes. Penetrative deformation is characterized by gently dipping mylonitic foliation across which northeast trending stretching lineation is everywhere developed. Prominent northwest trending fractures, dikes, and normal faults are orthogonal to the lineation. Most kinematic indicators in lower plate mylonitic rocks record top-to-the-southwest sense of shear. Upper plate stratigraphic sequences include Mesozoic supracrustal rocks, Tertiary volcanic and sedimentary rocks, and allochthonous Precambrian basement. Tilted blocks of upper plate strata generally overlie the mylonites along gently dipping detachment faults. Previously published $\mathrm{U}-\mathrm{Pb}$ and $\mathrm{K}-\mathrm{Ar}$ ages from lower plate granitic orthogneisses, upper plate volcanic sequences, and crosscutting dikes constrain the time of mylonitic deformation and detachment faulting in several of these areas to late Oligocene-early Miocene. Partitioning of extensional strain in Sonora was influenced by pre-Tertiary crustal structure. The belt of core complexes developed across two contrasting blocks of continental crust separated by the $\mathrm{N} 60^{\circ} \mathrm{W}$ striking Mojave-Sonora megashear. Portions of the southern Papago block (northeast of the megashear) consisting of Jurassic magmatic arc rocks and Upper JurassicCretaceous siliciclastic and carbonate strata resting upon a concealed, tectonically fragmented Precambrian basement were especially susceptible to crustal attenuation. Some core complexes of the southern Papago block occur within zones trending northwest that may coincide with Late Jurassic lineaments. In the Caborca block (southwest of the megashear), core complex-related rocks and structures have not been identified where surface exposures of Middle Proterozoic basement and overlying Upper Proterozoic-Paleozoic platform strata are common. However, extensional mylonitic fabrics are locally developed along the margins of a Tertiary two-mica granite batholith. Core complexes on both sides of the
\end{abstract}

Copyright 1994 by the American Geophysical Union.

Paper number 93TC03324.

0278-7407/94/93TC-03324\$10.00 megashear appear to be preferentially developed where Tertiary granites have intruded regions of crust with basement disrupted by pre-Tertiary structures. Sonoran core complexes preserve an extensional tectonic history comparable with that described from core complexes farther north in the United States and Canadian Cordillera. The timing of mid crustal extension in Sonora (25-18 Ma) is contemporaneous with the timing of core complex development in Arizona, Nevada, and Utah. Extension occurred later in these areas than in the Pacific Northwest-British Columbia region but earlier than in the Mojave Desert-Death Valley region. Middle Tertiary mylonitic fabrics of similar style and orientation have not been recognized farther south in Mexico. The southern terminus of the mid-Tertiary Cordilleran core complex belt appears to be in Sonora.

\section{Introduction}

\section{Purpose and Objectives}

Extensive regions of central and northem Sonora (Figure 1) are underlain by gneisses and schists with mylonitic fabrics. Much of this crystalline rock, once assumed to be Precambrian in age, is now known to have acquired its penetrative fabric during Tertiary time [Anderson et al., 1980; Silver and Anderson, 1984]. Deformational style at all scales is dominated by extensional structures similar to those documented in numerous metamorphic core complexes of the United States and Canadian Cordillera [Crittendon et al..,1980, and references therein]. Since the reconnaissance studies reported by Davis et al. [1981] and Silver and Anderson [1984], exposures of Tertiary gneiss and schist in Sonora have been interpreted as lower plates of metamorphic core complexes, remnants of normal slip, midcrustal shear zones. A primary objective of this paper is to document the lithologic and structural relationships within these core complexes. A second objective is to analyze possible influences of preTertiary crustal structure on the geographic distribution of core complexes in Sonora. Why are the core complexes developed in some areas but not in others?

Occurrences of Tertiary mylonite in Sonora (Figure 1) form a north-northwest trending belt extending from the latitude of 


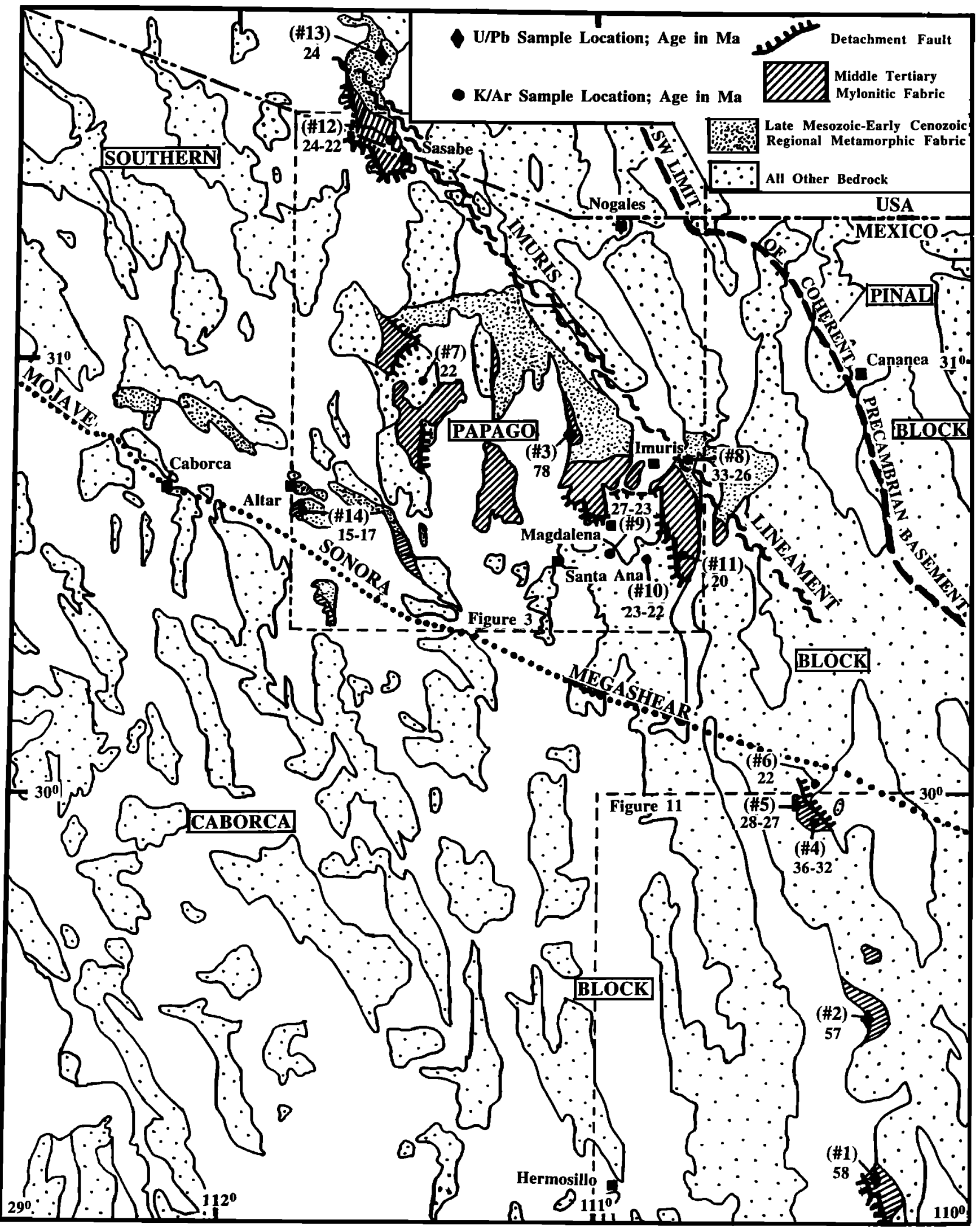

Figure 1. Map of northern and central Sonora showing the distribution of Tertiary metamorphic core complexes and published isotopic ages bearing on the timing of extension. Age sample locations are keyed to descriptions and citations in Table 1. Pre-Tertiary stratigraphic relationships in the Caborca block, southern Papago block, and Pinal block are summarized in Figure 2. 
Hermosillo to the international border. They are unevenly distributed on both sides of a hypothetical Late Jurassic transform fault known as the Mojave-Sonora megashear [Silver and Anderson, 1974; Anderson and Silver, 1979]. In terms of areal exposure, the core complexes are less conspicuous to the southwest of the megashear. We hypothesize that positioning of Tertiary granites and spatially associated mylonite zones was influenced by pre-Tertiary compositional heterogeneities and mechanical discontinuities in the Sonoran crust.

In the next section, we summarize the pre-Tertiary stratigraphy of three crustal blocks in northern and central Sonora, two of which host core complexes. Evidence for a middle Tertiary age of fabric development is tabulated from published work. Additionally, we describe field relationships and structural patterns from eight geographically distinct lower plate mylonite domains. In distinguishing the extensional mylonitic fabrics from preextensional fabrics, we are able to constrain the geometry and kinematics of several Tertiary shear zones. Detachment faults and upper plate rocks, where present, are briefly described. Finally, we point out likely pre-Tertiary structural controls on the partitioning of midcrustal extension across Sonora.

\section{Previous Work on Tertiary Extension in Sonora}

Subhorizontal foliations and lineations in gneissic granite bodies of Sonora were first mapped in ranges north of Magdalena and Santa Ana [Salas, 1968]. Apparent U-Pb ages from zircon in the Sierra Guacomea granodiorite gneiss (Figure 1 and Table 1) indicate a crystallization age of $78 \pm 3 \mathrm{Ma}$

Table 1. Published Geochronological Data Bearing on the Age of Extension in Sonoran Core Complexes

\begin{tabular}{|c|c|c|c|c|c|}
\hline $\begin{array}{l}\text { Map } \\
\text { Location }\end{array}$ & Lithology & $\begin{array}{l}\text { Local Geologic } \\
\text { Setting }\end{array}$ & $\begin{array}{l}\text { Dating } \\
\text { Technique }\end{array}$ & $\begin{array}{l}\text { Interpreted } \\
\text { Age, } \mathrm{Ma}\end{array}$ & Reference \\
\hline 1 Sierra & $\begin{array}{l}\text { gneissic } \\
\text { bio granite }\end{array}$ & $\begin{array}{l}\text { lower plate, } \\
\text { Mazatan complex }\end{array}$ & $\mathrm{U}-\mathrm{Pb}$ zircon & $58 \pm 2$ & Anderson et.al. [1980] \\
\hline $\begin{array}{l}2 \text { Puerto del } \\
\text { Sol }\end{array}$ & $\begin{array}{l}\text { foliated } 2- \\
\text { mica granite }\end{array}$ & $\begin{array}{l}\text { isolated lower } \\
\text { plate exposure }\end{array}$ & U-Pb zircon & $57 \pm 2$ & Anderson et al. [1980] \\
\hline $\begin{array}{l}3 \text { Sierra } \\
\text { Guacomea }\end{array}$ & $\begin{array}{l}\text { foliated bio } \\
\text { granodiorite }\end{array}$ & $\begin{array}{l}\text { lower plate, Magdalena- } \\
\text { Madera complex }\end{array}$ & $\mathrm{U}-\mathrm{Pb}$ zircon & $78 \pm 3$ & Anderson et al. [1980] \\
\hline 4 northern & 2-mica granite & lower plate, Aconchi & K-Ar plag & $36.5 \pm 0.8$ & Damon et al. $[1983 a, b]$ \\
\hline $\begin{array}{r}\text { Aconchi } \\
\text { batholith }\end{array}$ & & complex & K-Ar musc & $36.0 \pm 0.7$ & Damon et al. [1983a, b] \\
\hline 5 northern & hornblende & dikes intrude lower & K-Ar bio & $32.0 \pm-0.7$ & Damon et al. [1983a, b] \\
\hline $\begin{array}{r}\text { Aconchi } \\
\text { batholith }\end{array}$ & andesite & $\begin{array}{l}\text { plate granite, Aconchi } \\
\text { complex }\end{array}$ & $\begin{array}{l}\text { K-Ar whole } \\
\text { rock } \\
\text { (2 samples) }\end{array}$ & $\begin{array}{l}28.3 \pm 0.7 \\
26.7 \pm 0.6\end{array}$ & $\begin{array}{l}\text { Damon et al. }[1983 \mathrm{a}] \\
\text { Damon et al. }[1983 \mathrm{a}]\end{array}$ \\
\hline $\begin{array}{l}6 \text { northeast of } \\
\text { Aconchi } \\
\text { batholith }\end{array}$ & $\begin{array}{l}\text { basaltic } \\
\text { andesite }\end{array}$ & $\begin{array}{l}\text { flow in Baucurit } \\
\text { Formation, upper } \\
\text { plate, Aconchi complex }\end{array}$ & $\begin{array}{l}\text { K-Ar whole } \\
\text { rock }\end{array}$ & $21.7 \pm 0.4$ & Roldan-Quintana [1979] \\
\hline $\begin{array}{l}7 \text { Tubutama } \\
\text { basin }\end{array}$ & latite & $\begin{array}{l}\text { flow in upper plate } \\
\text { sedimentary sequence, } \\
\text { Tubutama complex }\end{array}$ & $\begin{array}{l}\text { K-Ar whole } \\
\text { rock }\end{array}$ & $22.3 \pm 0.6$ & $\begin{array}{l}\text { Gomez-Caballero et al. } \\
\text { [1981] }\end{array}$ \\
\hline $\begin{array}{l}8 \text { northern } \\
\text { Sierra de la } \\
\text { Madera }\end{array}$ & $\begin{array}{l}\text { 2-mica } \\
\text { granite }\end{array}$ & $\begin{array}{l}\text { lower plate, Magdalena- } \\
\text { Madera complex }\end{array}$ & $\begin{array}{l}\text { K-Ar bio } \\
\text { (2 samples) }\end{array}$ & $\begin{array}{l}33.2 \pm 0.7 \\
26.3 \pm 0.6\end{array}$ & $\begin{array}{l}\text { Gilmont }[1978] \\
\text { Damon, pers. comm., } \\
{[1990]}\end{array}$ \\
\hline $\begin{array}{l}9 \text { Sierra la } \\
\text { Ventana }\end{array}$ & $\begin{array}{r}\text { alkalic } \\
\text { latite }\end{array}$ & $\begin{array}{l}\text { upper plate, Magdalena- } \\
\text { Madera complex }\end{array}$ & $\begin{array}{l}\text { K-Ar whole } \\
\text { rock } \\
\text { (5 samples) }\end{array}$ & $\begin{array}{l}27.3 \pm 0.6 \\
\text { to } \\
22.7 \pm 0.5\end{array}$ & $\begin{array}{l}\text { Miranda-Gasca and } \\
\text { de Jong, } 1992\end{array}$ \\
\hline $\begin{array}{l}10 \text { Magdalena } \\
\text { basin }\end{array}$ & $\begin{array}{l}\text { basaltic } \\
\text { andesite }\end{array}$ & $\begin{array}{l}\text { upper plate, Magdalena- } \\
\text { Madera complex }\end{array}$ & $\begin{array}{l}\text { K-Ar whole } \\
\text { rock } \\
\text { (3 samples) }\end{array}$ & $\begin{array}{l}22.7 \pm 0.4 \\
\text { to } \\
21.6 \pm 1.0\end{array}$ & $\begin{array}{l}\text { Miranda-Gasca and } \\
\text { de Jong [1992] }\end{array}$ \\
\hline $\begin{array}{l}11 \text { southern } \\
\text { Sierra de } \\
\text { la Madera }\end{array}$ & rhyolite & $\begin{array}{l}\text { dike intrudes lower } \\
\text { plate mylonitic granite } \\
\text { and upper plate } \\
\text { conglomerate }\end{array}$ & $\begin{array}{l}\text { K-Ar whole } \\
\text { rock }\end{array}$ & $19.8 \pm 0.4$ & $\begin{array}{l}\text { Miranda-Gasca and } \\
\text { de Jong [1992] }\end{array}$ \\
\hline $\begin{array}{l}12 \text { southern } \\
\text { Baboquiveri } \\
\text { Mountains }\end{array}$ & microdiorite & $\begin{array}{l}\text { dikes intrude lower } \\
\text { plate mylonitic } \\
\text { granite }\end{array}$ & $\begin{array}{l}\text { K-Ar whole } \\
\text { rock } \\
\text { (2 samples) }\end{array}$ & $\begin{array}{l}24 \pm 2 \\
22.4 \pm 0.6\end{array}$ & $\begin{array}{l}\text { Goodwin and Haxel } \\
\text { [1990] }\end{array}$ \\
\hline $\begin{array}{l}13 \text { southern } \\
\text { Baboquiveri } \\
\text { Mountains }\end{array}$ & $\begin{array}{l}\text { rhyolite } \\
\text { porphyry }\end{array}$ & $\begin{array}{l}\text { intrudes microdiorite } \\
\text { dikes of site } 12\end{array}$ & U-Pb zircon & $24 \pm 2$ & $\begin{array}{l}\text { Goodwin and Haxel } \\
\text { [1990] }\end{array}$ \\
\hline $\begin{array}{l}14 \text { Cerro } \\
\text { Carnero }\end{array}$ & $\begin{array}{l}\text { biotite schist } \\
\text { muscovite } \\
\text { schist } \\
\text { foliated biotite } \\
\text { granodiorite }\end{array}$ & $\begin{array}{l}\text { roof rocks of Carnero } \\
\text { pluton, lower plate, } \\
\text { Camero complex } \\
\text { lower plate, Carnero } \\
\text { complex }\end{array}$ & $\begin{array}{l}\text { K-Ar bio } \\
\text { K-Ar musc } \\
\quad(2 \text { samples }) \\
\text { K-Ar bio }\end{array}$ & $\begin{array}{l}16.9 \pm 0.6 \\
16.2 \pm 0.5 \\
16.1 \pm 0.5 \\
14.8 \pm 0.5\end{array}$ & $\begin{array}{l}\text { Hayama et al. }[1984] \\
\text { Hayama et al. }[1984] \\
\text { Hayama et al. }[1984] \\
\text { Hayama et al. }[1984]\end{array}$ \\
\hline
\end{tabular}


[Anderson et al., 1980]. This age demonstrated the occurrence of post-Precambrian tectonism in the Santa Ana region. Additional geochronological work nearby and in other parts of Sonora led to the identification of several more granitic orthogneisses (Figure 1) whose penetrative mylonitic fabrics formed during Tertiary time [Anderson et al., 1980; Silver and Anderson, 1984; Roldan-Quintana, 1991].

One common problem in recent studies [Davis et al., 1981; Nourse, 1989, 1990; De Jong et al., 1988; Jacques-Ayala et al., 1990; G. B. Haxel and T. H. Anderson, unpublished data, 1981) has been to distinguish metamorphic and deformational fabrics of Tertiary age from older fabrics which themselves may be polygenetic. Three episodes of ductile fabric development may have occurred in the region since Late Jurassic time, with the relative importance of each event a matter of debate. As described later, Tertiary extensional structures in Sonora may be recognized by a regionally consistent orientation and style.

The metamorphic core complexes shown in Figure 1 include all known outcrops of mylonite derived from Tertiary granitoids and nearby country rocks. These layered rocks are commonly overlain in low-angle fault contact by essentially unmetamorphosed middle Tertiary or older rocks. Figure 1 distinguishes areas with Tertiary extensional mylonitic fabric from areas with Late Jurassic or Laramide metamorphic fabric. $\mathrm{K}$-Ar ages from some upper plate volcanic rocks and from dikes which crosscut detachment zones (Table 1) place an early Miocene upper limit on the timing of detachment faulting.

From recent to middle Miocene, tectonic activity in Sonora has been dominated by postdetachment "Basin and Range style" block faulting. Most ranges of the region are bounded by steep, north striking normal faults. Adjacent valleys are filled with late Cenozoic detritus (Figures 3 and 11). Northwest and northeast trends exist but are less pronounced.

\section{Geologic Framework}

\section{Pre-Tertiary Crustal Structure of Sonora}

In Sonora, as in adjacent parts of Arizona and other parts of the Basin and Range province, Cenozoic extensional tectonic processes were imposed upon continental crust of heterogeneous structure and composition (Figures 1 and 2). Pre-Jurassic crust in central and northern Sonora is composed of two distinct Middle Proterozoic crystalline provinces overlain by Upper Proterozoic and/or Paleozoic and Early Mesozoic platform strata. The provınces underlain by Precambrian crust (Caborca block in the southwest and Pinal block in the northeast) are separated by a belt of Jurassic plutonic, volcanic, and sedimentary rocks which we refer to as the southern Papago block. All three blocks are intruded by Late Cretaceous plutons and batholiths [Anderson and Silver, 1974, 1977; Silver and Chappell, 1988]. However, only portions of the Caborca block and the southern Papago block are hosts to Tertiary metamorphic core complexes (Figure 1). Pre-Tertiary stratigraphic relationships within the three blocks are summarized in Figure 2.

Pinal block. Precambrian basement that extends into Sonora from southern Arizona is composed of $1.68 \mathrm{Ga}$ Pinal Schist and younger Mid-Proterozoic intrusives, overlain by Upper Proterozoic-Paleozoic platform strata [Cooper and
Silver, 1964; Anderson and Silver, 1977; Davis, 1980, and references therein]. Along an irregular contact near the international border the Precambrian and Paleozoic rocks are overlain and intruded by Jurassic volcanic and plutonic rocks. Southwest of a line between Nogales and Cananea, the basement for the Jurassic sequence is not exposed.

Southern Papago block. Jurassic rocks form a northwest trending belt that separates the two Precambrian provinces. The distinctive lithologic assemblage, which includes volcanic, plutonic, and sedimentary rocks, was named the "Papago terrane" where mapped in south-central Arizona [Haxel et al., 1984]. We adopt the name "southern Papago block" for the continuation of similar lithologies in Sonora. The Jurassic rocks compose part of a continental margin magmatic arc [Anderson and Silver, 1978; Tosdal et al., 1988]. Portions of this arc in Sonora and southern Arizona were broken by northwest trending faults during Late Jurassic time, creating elongate basins that filled with syntectonic conglomerate and younger Lower Cretaceous marine strata [Titley, 1976; Bilodeau et al., 1987, Kitz and Anderson, 1988; Nourse, 1990; Jacques-Ayala et al., 1990]. One of these faults, the Mojave-Sonora megashear, forms the abrupt southwestern boundary of the southern Papago block [Anderson and Silver, 1979]. Jurassic strata adjacent to the megashear are highly deformed by thrusts and folds.

Caborca block. The second Precambrian province, which lies southwest of the megashear, includes widespread exposures of Mid-Proterozoic granite and gneiss unconformably overlain by a thick Upper ProterozoicPhanerozoic supracrustal sequence. Postulated correlation of these rocks to a stratigraphic section preserved in the Inyo Mountains of eastern California provided one of the early arguments for large scale sinistral displacement on the megashear [Silver and Anderson, 1974]. Most of the basement exposed south of Caborca appears to be structurally autochthonous. Near the megashear, however, mapped exposures of basement may overlie Mesozoic rocks along lowangle faults [Anderson et al., 1984; Rodriguez-Castaneda, 1986].

\section{Early-Middle Tertiary Magmatism and Sedimentation in Sonora and Southern Arizona}

A record of latest Cretaceous-early Tertiary (Laramide) orogenesis and peraluminous magmatism analogous to that described in the Papago terrane [Haxel et al., 1984] may be preserved within portions of the southem Papago block of Sonora. Two-mica granite of known or suspected Paleogene age intrudes regionally metamorphosed and deformed rocks in several localities [Silver and Anderson, 1984; Nourse, 1989]. Fabrics in these metamorphic rocks record different deformational conditions and structural styles than do the younger mylonitic fabrics. Ongoing debate centers on whether the age of the older fabrics is Late Jurassic or Laramide. Structures of both ages are very likely preserved locally.

Laramide orogenesis in southem Arizona was followed by the accumulation of predominantly conglomeratic lower(?) to middle Tertiary sediments in broad continental basins [Eberly and Stanley, 1978]. Upward in the Cenozoic sequence, 


\section{CABORCA BLOCK :}

\section{SOUTHERN PAPAGO BLOCK :}

PINAL BLOCK:

\begin{tabular}{|c|c|}
\hline $\begin{array}{l}\text { LATE } \\
\text { CRETACEOUS }\end{array}$ & La Palma Formation: \\
\hline $\begin{array}{l}\text { EARLY } \\
\text { CRETACEOUS }\end{array}$ & - Bisbee Groun $: \because 1=$ \\
\hline $\begin{array}{l}\text { LATE } \\
\text { JURASSIC }\end{array}$ & G. Glance Conglomer \\
\hline $\begin{array}{l}\text { MIDDLE } \\
\text { JURASSIC }\end{array}$ & $\begin{array}{l}\text { (generally } \\
\text { not exposed) }\end{array}$ \\
\hline $\begin{array}{l}\text { EARLY } \\
\text { JURASSIC }\end{array}$ & - Antimonio Fo \\
\hline TRIASSIC & - tectonic contact with -3 \\
\hline PALEOZOIC & \\
\hline $\begin{array}{l}\text { LATE } \\
\text { PROTEROZOIC }\end{array}$ & \\
\hline $\begin{array}{l}\text { MIDDLE } \\
\text { PROTEROZOIC }\end{array}$ & $\begin{array}{l}\text { layered gneiss, schist, } \\
\text { and amphibolite, intruded } \\
\text { by } 1.7 \mathrm{Ga}, 1.4 \mathrm{Ga} \text {, and } \\
1.1 \mathrm{Ga} \text { granite }\end{array}$ \\
\hline
\end{tabular}
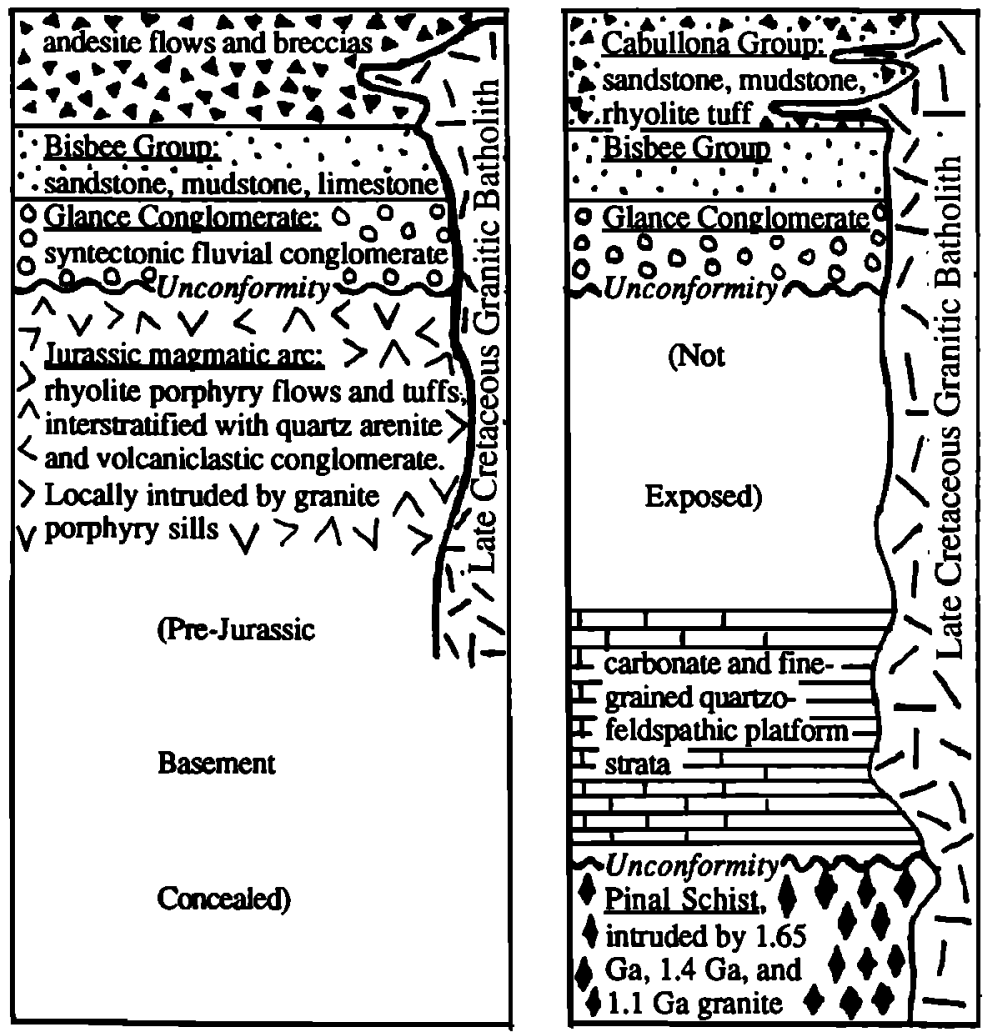

Figure 2. Simplified stratigraphic columns showing contrasting pre-Tertiary geology in three crustal blocks of northem and central Sonora. Patterns for rock units correspond to pre-Tertiary geology mapped in Figures 3 and 11. Stratigraphic nomenclature and age constraints are compiled from studies by Taliaferro [1933], Valentine, 1936; Cooper and Silver [1964], Salas [1968], Silver and Anderson [1974], Anderson and Silver 1974, 1977, 1978, 1979, 1981], Corona [1979], Davis [1980], Gonzales-Leon [1980], Stewart et al. [1984], Montano, 1984; Haxel et al. [1984], Bilodeau, et al. [1987], Silver and Chappell [1988], Tosdal et al. [1988], Gonzales-Leon and Jacques-Ayala [1988], Kitz and Anderson 1988], Nourse [1989, 1990], Jacques-Ayala et al. [1990].

volcanic rocks with $\mathrm{K}$-Ar ages between 30 and $25 \mathrm{Ma}$ become progressively more abundant [Damon and Mauger, 1966; Shafiqullah et al., 1980]. In Sonora, similar sedimentary/ volcanic sequences have been described south of Magdalena [Nourse, 1989; Miranda-Gasca and De Jong, 1992], in the vicinity of Tubutama [Frye, 1975; Gomez-Caballero et al., 1981], and near the margins of the Aconchi batholith [RoldanQuintana, 1979].

Timing of Ductile Deformation in Metamorphic Core Complexes of Sonora and Arizona

Controversy has commonly accompanied discussions of the timing of ductile deformation in Cordilleran metamorphic core complexes. The issue is complicated by two problems. (1) Many of the ductile fabrics are polygenetic. 2) Intrusions used to date the fabrics have commonly experienced complex thermal histories. Among some core complexes in Sonora and southern Arizona, study of $\mathrm{K}-\mathrm{Ar}, \mathrm{Rb}-\mathrm{Sr}$, and $\mathrm{U}-\mathrm{Th}-\mathrm{Pb}$ isotopic systems has facilitated geochronological interpretation of lower plate gneisses [Shakel et al., 1977; Anderson et al.,
1980; Shafiqullah et al., 1980; Wright et al., 1981, 1986; Silver and Anderson, 1984; Reynolds et al., 1986, 1988; Gehrels and Smith, 1991; Goodwin and Haxel, 1990]. Table 1 and Figure 1 summarize existing geochronological data and sample locations from Sonora that bear on the timing of metamorphic core complex development.

Geochronological comparison of lower and upper plates of core complexes from Sonora and Arizona indicates that the two regions shared similar histories of thermal activity and fabric development during Mesozoic and Tertiary time. Many of the core complexes record one or more periods of Mesozoic ductile deformation. Related metamorphic fabrics may be intruded by postkinematic two-mica granite of Paleogene age [Anderson et al., 1980; Haxel et al., 1984]. Mylonitic fabrics and brittle structures related to detachment faulting are late and overprint granite and volcanic strata. Some of the granite bodies that record mylonitic deformation yield early Miocene $\mathrm{U}-\mathrm{Pb}$ ages [Reynolds et al., 1986; Wright et al., 1986; Gehrels and Smith, 1991]. Thus ductile deformation in many areas persisted to the beginning of Miocene time. Widespread, 
nearly coeval $\mathrm{K}$-Ar ages show that the culminating processes of lower plate cooling, coupled with tectonic unroofing of upper plate, occurred throughout most of the region between about 25 and $18 \mathrm{Ma}$ [Silver and Anderson, 1984; Reynolds et $a l ., 1988 ;$ Table 1].

\section{Tertiary Gneiss and Schist in Sonora}

Rocks in Sonora that record ductile deformation of Tertiary age may be recognized by the remarkably systematic orientation of northeasterly trending stretching lineation developed upon subhorizontal foliation. This distinctive mylonitic fabric is known to be imposed upon Paleocene granite [Anderson et al., 1980] and is therefore Tertiary in age. The fabric commonly extends into the country rocks adjacent to dated plutons and although considerable variation in intensity exists, consistently oriented structural elements have been mapped and correlated in rocks far from dated samples. Outcrops of Tertiary gneiss and schist form a northnorthwest trending belt extending from Mazatan through the border town of Sasabe [Anderson et al., 1980; Figure 1]. Penetratively deformed rocks are not exposed continuously within this band but occur as domains segmented by sharp or transitional boundaries.

Exposures of Tertiary mylonite in northern and central Sonora are subdivided below into eight geographic domains. Five of these domains occur within or near the southwest part of the southern Papago block (Figure 3). Portions of the Magdalena-Madera domain and the Jarillas-Potrero-Tortuga domain were mapped by Salas [1968], Anderson et al. [1980], and Nourse [1989]. Data from the Tubutama-Mesquital domain were collected during reconnaissance work by G. B. Haxel and T. H. Anderson (unpublished data, 1981) and Nourse (unpublished data, 1987). Various parts of the Pozo Verde domain have been mapped by Davis [1980], Davis et al. [1981], Haxel et al. [1982], and Goodwin and Haxel [1990]. Portions of the Camero domain have been studied by T. H. Anderson and L. T. Silver (unpublished data, 1979), Hayama et al. [1984], and Jacques-Ayala et al. [1990]. The three remaining Tertiary mylonite domains are exposed southwest of the megashear within the Caborca block (Figure 11). Our description of the Aconchi domain draws upon the work of Roldan-Quintana [1991]. Field reconnaissance in the Puerto del Sol and Mazatan domains was carried out by T. Anderson (unpublished data, 1979), and compliments contemporaneous work such as that by Peabody [ 1979].

\section{Core Complexes Developed in the Southern Papago Block}

\section{General Character and Boundaries}

The widest part of the Tertiary core complex belt is in the southern Papago block between the Imuris lineament and the Mojave-Sonora megashear (Figure 3). Within this region, Tertiary gneiss and schist have formed from predominantly supracrustal rocks of Jurassic and Early Cretaceous age intruded by Late Cretaceous and younger plutons [Anderson and Silver, 1979; Anderson et al., 1980; Montano, 1984; Nourse, 1989. 1990]. Away from the outcrops of mylonitic rocks, volcanic and volcaniclastic Jurassic strata are commonly folded along west and northwest trending axes, and lineation directions may differ from the regionally consistent northeast trend of the Tertiary mylonites [Corona, 1979; Nourse, 1989].

The Imuris lineament, which bounds core complexes of the southern Papago block, separates unmetamorphosed crust to the northeast from ductilely extended crust to the southwest. This northwest trending lineament is the most prominent of a series of fractures that segment ranges between Nogales and Caborca (Figures 1 and 3). It separates Sierra Cibuta from the Sierras Guacomea, Jojoba, and Magdalena to the southwest. Jurassic volcanic strata composing Sierra Cibuta lack mylonitic foliation and stretching lineation. At the lineament a slight increase in metamorphism is evident in the recrystallization of the groundmass of lithologically similar quartz porphyry. Lineation and foliation parallel to the regional Tertiary orientation intensify to the southwest and become penetrative within $5 \mathrm{~km}$ of the lineament. Similar relationships may be observed to the northwest in the vicinity of El Correo.

Southeast of Imuris, granitic rocks of the northern Sierra de la Madera display a very weak Tertiary fabric where intersected by the Imuris lineament. Within a few kilometers to the southwest, well-developed mylonitic foliation is characteristic. Northwest trending mafic dikes are also common near the lineament. These dikes intrude the Tertiary fabric and appear to mark a localized region of brittle extension.

If the Imuris lineament is projected northwestward across the international border, it intersects the southern Baboquivari Mountains of Arizona (Figure 3). Within a 10-km-wide zone, swarms of northwest trending microdiorite and rhyolite dikes intrude metamorphosed Jurassic rocks and weakly to strongly foliated Paleocene(?) two-mica granite [Haxel et al., 1982; Goodwin and Haxel, 1990]. As in the Sierra Madera, these dikes strike orthogonal to mylonitic stretching lineation observed in the granite [Goodwin and Haxel, 1990]. They also mark the approximate position of a northwest trending mylonitic front.

Two isolated exposures of Tertiary gneiss and schist occur near the Mojave-Sonora megashear (Figure 3). At Cerro Carnero, characteristic Tertiary mylonitic fabric is superimposed on granites that have intruded Jurassic and Cretaceous supracrustal rocks with Late Jurassic and/or Laramide structures. At Cerro Prieto, strongly recrystallized marble, quartzite, and diorite display locally well-developed stretching lineations of the Tertiary trend.

Throughout the southern Papago block, individual exposures of Tertiary mylonite are bounded by either low-angle or highangle normal faults. Where exposed, the structurally highest portions of mylonitic sections terminate abruptly against unmetamorphosed Lower Cretaceous or Tertiary rocks. Brittle detachment faults mark the boundary between lower and upper plates. The detachment faults in tum are broken by steep normal faults which may strike north, northwest, or northeast (Figure 3).

\section{Magdalena-Madera}

This region is named for the prominent Tertiary mylonite zone and associated detachment fault exposed in Sierra Magdalena and Sierra de la Madera (Figures 3-5). Pre-middle 


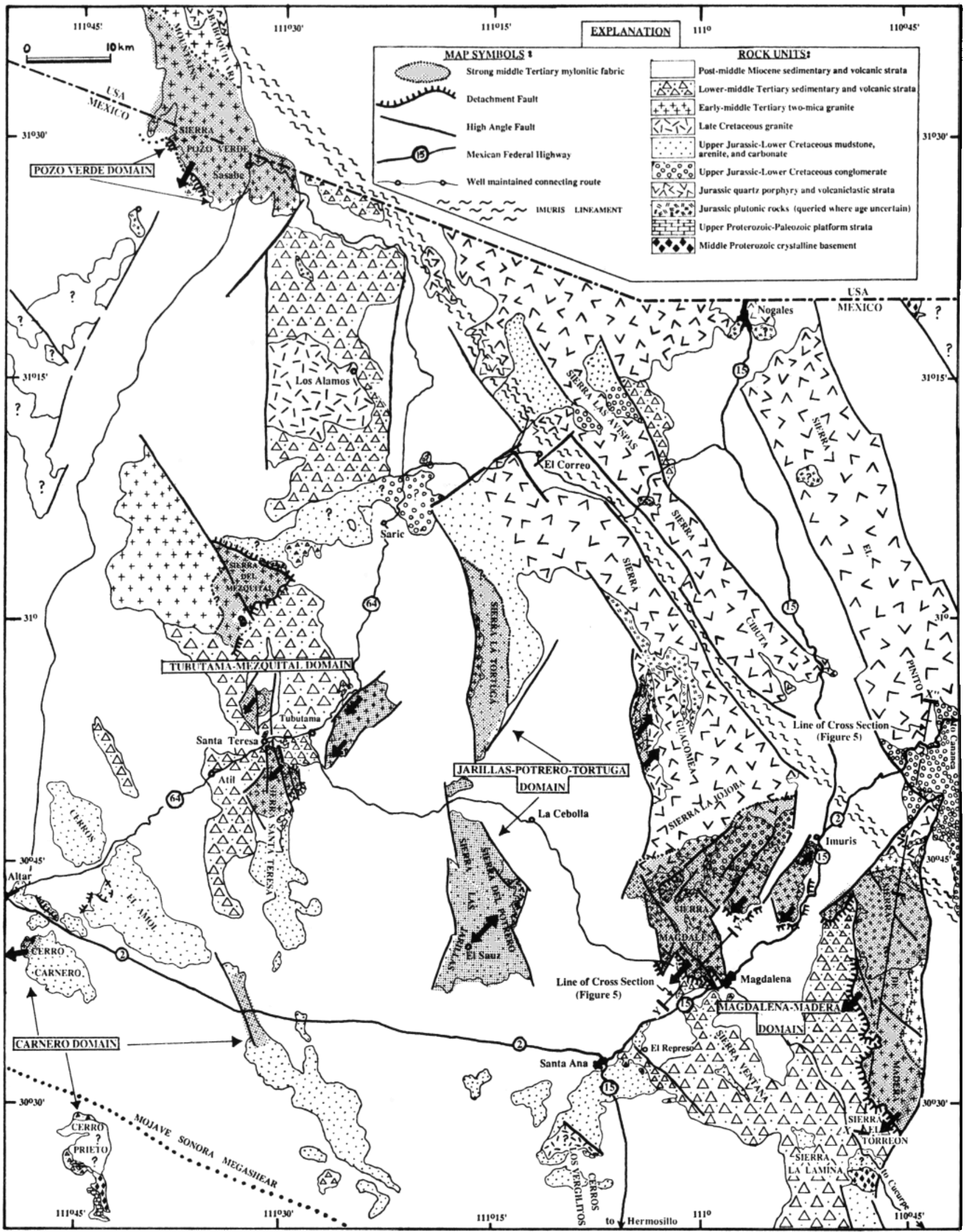

Figure 3. Geologic map showing core complexes developed in the southern Papago block. Solid black arrows indicate direction of upper plate detachment recorded by lower plate fabrics. Structural data from the five designated lower plate mylonite domains are presented in Figures 6-10. 
Cretaceous rocks of the lower plate consist of Jurassic thyolite porphyry, quartz arenite, conglomerate, and intrusive granite porphyry overlain by quartz-sandstone-volcanic pebble conglomerate in turn overlain by Lower Cretaceous marine sediments similar to the Bisbee Group of southeastern Arizona. This supracrustal section is intruded by two generations of granite and records at least two periods of ductile deformation [Nourse, 1989, 1990].

Folds, stretched pebbles, and metamorphic fabrics associated with the older deformation(s?) are developed in the Jurassic rocks (Figures 4-6). Preextensional fabric may also be present in the $78 \pm 3 \mathrm{Ma}$ Sierra Guacomea granodiorite gneiss [Anderson et al., 1980]. Early and middle Tertiary two-mica granite intrudes both of these foliated units. Prograde metamorphic assemblages preserved in pelitic country rocks of the Tertiary plutons have reached lower amphibolite grade (staurolite-andalusite-biotite-muscovite-quartz) conditions.

Mylonitic fabric with systematically oriented shallowdipping compositional foliation (S) and discrete displacement surfaces (C) has been imposed upon all of the above lithologies and structures. The mylonitic rocks define a 1 to 3 km-thick southwest vergent noncoaxial shear zone (Figure 5) that records a minimum of 9-km displacement [Nourse, 1989]. Lower Cretaceous marine beds and lower(?) to middle Tertiary sedimentary and volcanic rocks are separated from the mylonite zone by the Magdalena detachment fault. This surface is marked by a narrow zone of chloritic and sericitic microbreccias, formed by cataclasis and retrograde alteration of lower plate mylonite. Farther south in the upper plate, Precambrian gneiss and granite structurally overlie folded Mesozoic sedimentary and volcanic strata [Anderson et al., 1984].

Structural elements in the lower plate of the MagdalenaMadera core complex may be separated on the basis of orientation and style. Tertiary mylonitic fabric is characterized by shallow-dipping $S$ foliation and stretching lineation oriented uniformly $\mathrm{N} 30^{\circ}-50^{\circ} \mathrm{E}$ (Figures 4 and $6 \mathrm{a}-\mathrm{c}$ ). The $S$ foliation is associated with discrete $C$ surfaces which strike parallel to and dip $5^{\circ}$ to $30^{\circ}$ more steeply southwestward than the $S$ planes (Figure $6 \mathrm{c}$ ). The sense of displacement of most $\mathbf{C}$ surfaces is top-to-the-southwest except locally, near the northeast margin of the Tertiary fabric domain, where northeast dipping normal sense shear planes are present. Broad folds about axes with northwest trends are developed in detached upper plate rocks (Figure 4). Locally, mylonitic foliation in the lower plate is similarly folded. Rotation of the shear zone during or subsequent to uplift and cooling of the lower plate is implied by a swarm of crosscutting mafic dikes in the northem Sierra de la Madera that dip consistently southwest (Figure 6c).

Some rocks of the lower plate preserve relict structures of contrasting orientation and style to those of the overprinted Tertiary fabric (Figures 4 and $6 \mathrm{~d}$ ). Lineations defined by stretched cobbles in Jurassic conglomerate and stretched feldspars in Jurassic rhyolite porphyry trend east-west to $\mathrm{N} 75^{\circ} \mathrm{W}$ in the northern Sierra Madera, and $\mathrm{N} 10^{\circ}-25^{\circ} \mathrm{E}$ in the northwestern Sierra Guacomea. Map scale open folds with west trending axes are common. The fabric in these rocks is crystalloblastic or schistose rather than mylonitic and is intruded by an early Tertiary(?) two-mica granite in the Sierra de la Madera [Nourse, 1990]. In the central Sierra Magdalena, the early structures are overprinted by Tertiary fabric, and a systematic reorientation of the older lineations can be demonstrated [Nourse, 1989].

\section{Jarillas-Potrero-Tortuga}

This domain includes metamorphic rocks originally mapped by Salas [1968] in Sierras las Jarillas, el Potrero, and la Tortuga. Exposures occur in crudely north-south ranges bounded by steep normal faults with north, northwest, and northeast strikes (Figure 3). No detachment faults or upper plate strata have been recognized in the immediate area.

In Sierra las Jarillas and Sierra el Potrero, complexly deformed metasedimentary rocks are intruded by sills and dikes of leucocratic two-mica granite and pegmatite. Mylonitic fabric is superimposed on all lithologies. Components of the metasedimentary sequence include pelitic schist, marble, finegrained biotite-feldspar-quartz schist, stretched-pebble conglomerate, and horblende-plagioclase-quartz schist. Mineral assemblages indicative of upper amphibolite facies are preserved in some of the pelite and marble [Salas, 1968], but the majority of these rocks are pervaded with chlorite and epidote indicative of the greenschist facies.

On the east face of Sierra el Potrero, calcareous and quartzose metasedimentary rocks overlie a thick sequence of massive, fine-grained quartzofeldspathic gneiss and feldspar-quartzmuscovite-biotite schist, which may be derived from volcanic and volcaniclastic protoliths of the Jurassic arc. The metasedimentary strata are possibly correlative with fossiliferous Lower Cretaceous beds exposed to the southeast [Salas, 1968] and southwest [Jacques-Ayala et al., 1990]. Alternatively, they may represent an upper level of the Jurassic arc or a southeastern occurrence of the Upper JurassicLower Cretaceous McCoy Mountains formation, as suggested by the presence of amphibolitic schists, possibly derived from andesitic or basaltic flows.

Along the lower slopes of the western Sierra la Tortuga, an east dipping metamorphic sequence is concordantly intruded by a small leucocratic two-mica granite pluton. Pegmatite dikes associated with this pluton are abundant in the metamorphic strata to the southeast. A protomylonitic fabric is developed in the pluton, particularly near its upper margin. The metamorphic rocks are mostly derived from a fine-grained Jurassic(?) or Lower Cretaceous(?) sedimentary protolith. Andalusite, cordierite, and biotite occur abundantly in pelitic

Figure 4. Tectonic map of the Magdalena-Madera core complex showing the Magdalena detachment fault [Nourse, 1989, 1990] and the distribution of lower plate ductile fabrics and structures. Middle Tertiary extensional mylonitic fabric is differentiated from pre-middle Tertiary crystalloblastic fabric and associated folds. Also shown are broad folds which affect both the lower plate mylonitic foliation and detached upper plate rocks. 
NOURSE ET AL.: TERTIARY CORE COMPLEXES, SONORA, MEXICO
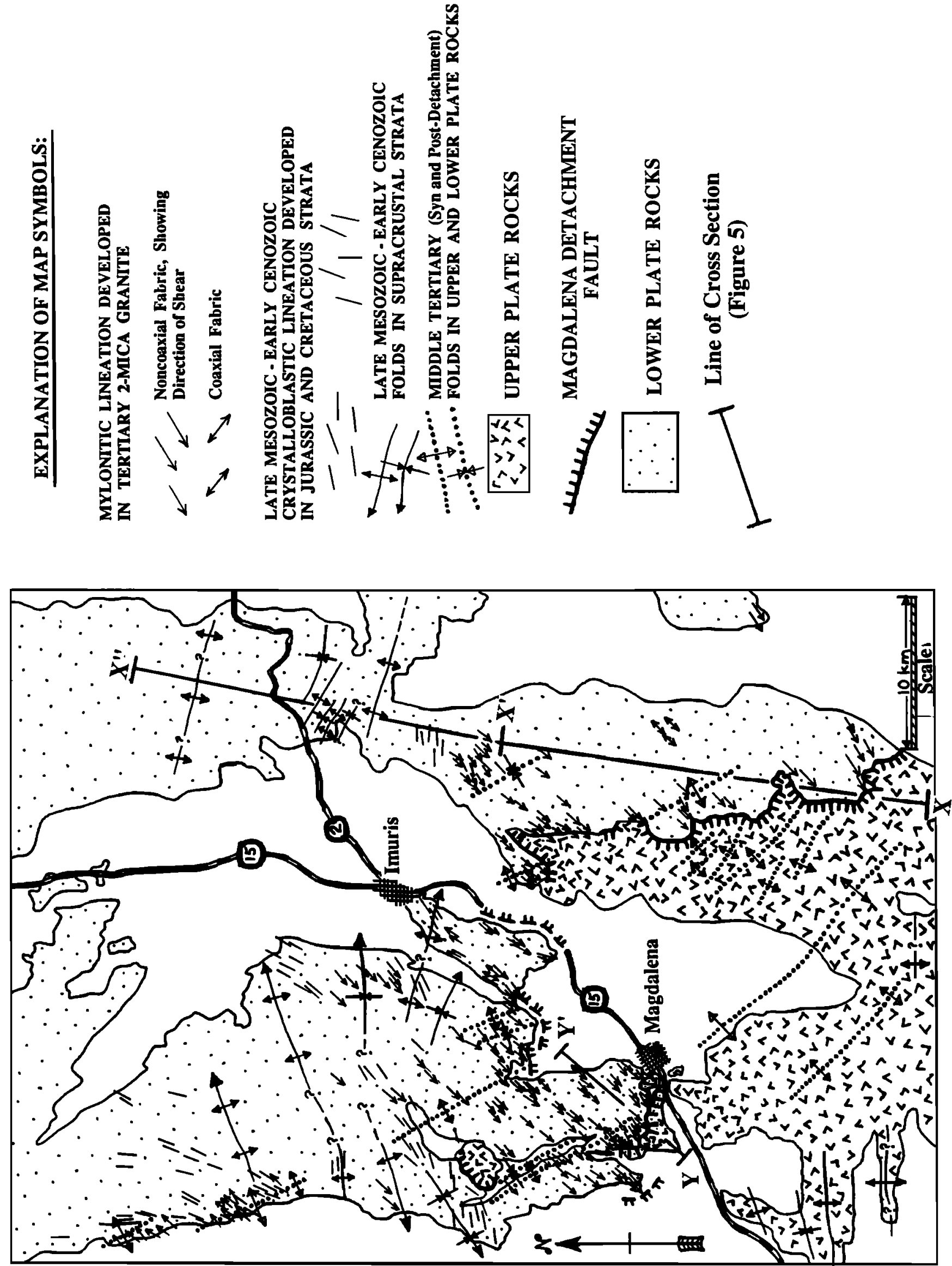


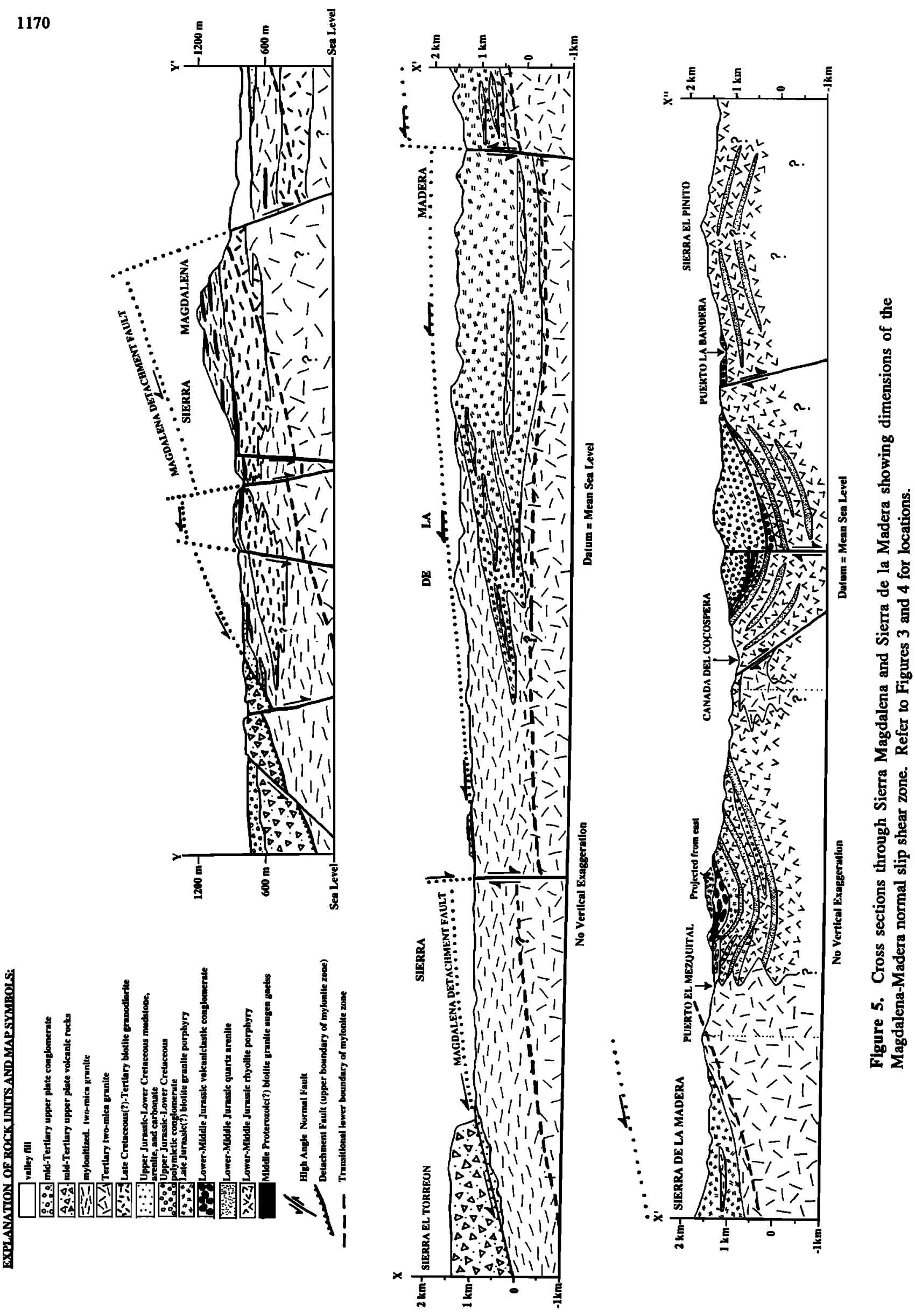



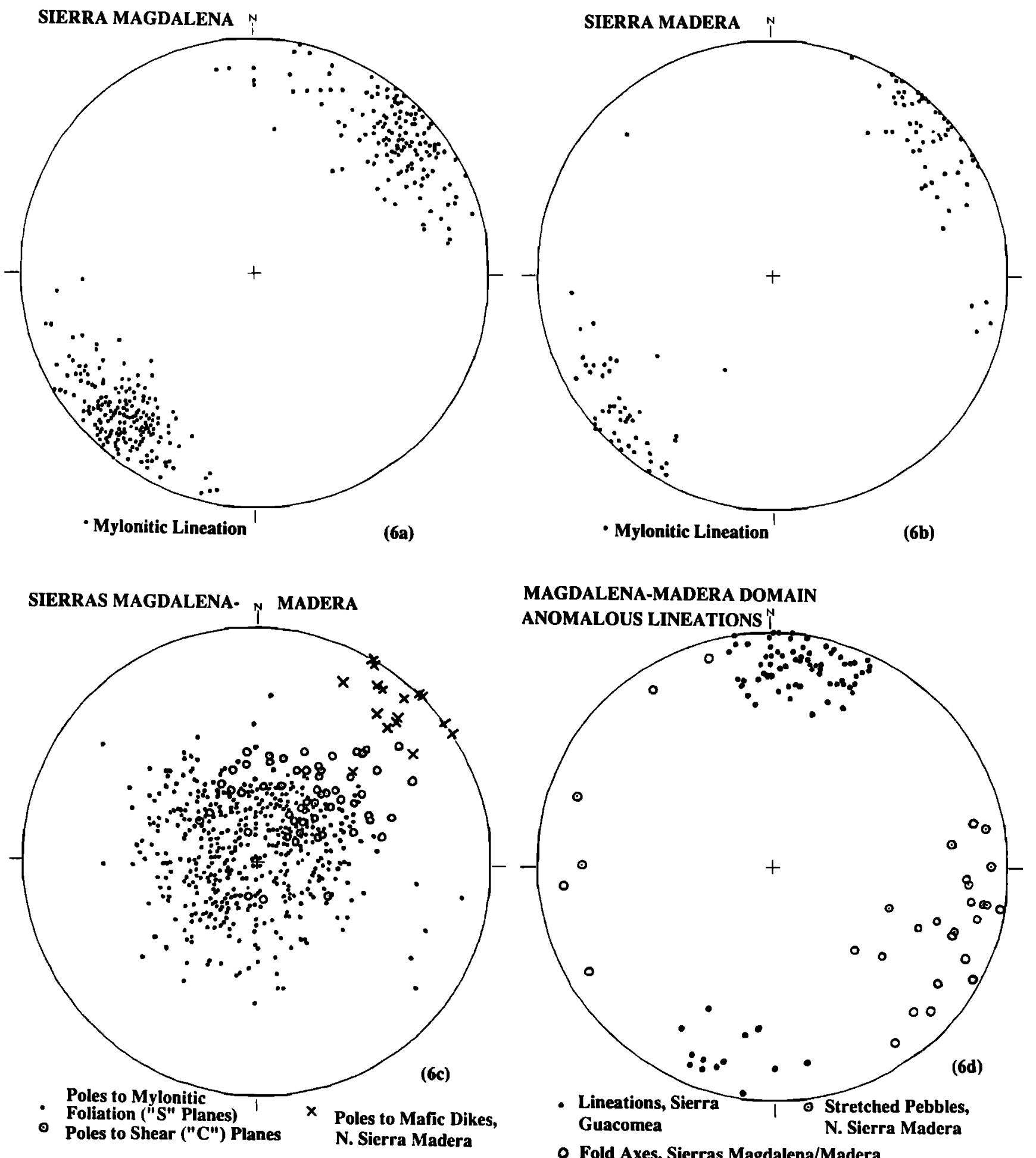

- Fold Axes, Sierras Magdalena/Madera

Figure 6. Lower hemisphere equal-area projections of structural elements from the Magdalena-Madera domain; (a) middle Tertiary mylonitic lineation from Sierra Magdalena, (b) mylonitic lineation from Sierra de la Madera, (c) poles to mylonitic foliation ("S") and shear planes ("C") measured in lower plate mylonitized granite (poles to postmylonitic microdiorite dikes also shown), and (d) pre-middleTertiary crystalloblastic lineation developed in lower plate Jurassic and Cretaceous rocks. 
schist within $100 \mathrm{~m}$ of the pluton, whereas chlorite, biotite, and epidote characterize phyllite at higher structural positions.

Two generations of ductile fabric may be recognized within the Jarillas-Potrero-Tortuga domain. A pregranite strain event is characterized by foliation, developed during greenschist to amphibolite facies metamorphism, and stretched pebbles with westerly or northwesterly trends subparallel to isoclinal fold axes (Figure 7a). Near Rancho el Sauz the metamorphic strata exhibit meter scale overturned folds with consistently oriented, northeast dipping axial planes. The older structures are intruded by dikes and sills of pegmatite and leucogranite which in turn display mylonitic foliation (Figure $7 \mathrm{~b}$ ) and lineation (Figure 7c) and local boudinage. Mylonitic lineation, marked by smeared and stretched quartz, micas, and feldspar, is best developed away from the fold hinges. This lineation is parallel to the characteristic Tertiary trend (i.e., $\mathrm{N} 30^{\circ}-50^{\circ} \mathrm{E}$, Figure $7 \mathrm{c}$ ). Kinematic indicators and S-C fabrics studied in about 10 outcrops and thin sections yielded both northeast and southwest vergences.

\section{Tubutama-Mezquital}

Mylonitic two-mica granite and schist underlie several small ranges and hills in the vicinity of Tubutama (Figure 3 ). The most prominent of these ranges, Sierra Santa Teresa, is bounded on the east by a north trending, high-angle normal fault, well exposed in excavations near Cautemoc dam. The upthrown block is composed of an east dipping, mylonitized two-mica granite, locally capped by muscovite-quartz-chloritecordierite(?) schist. Cerro la Campana, $10 \mathrm{~km}$ to the northeast, is underlain by two-mica granite that displays a penetrative subhorizontal mylonitic fabric. Lowlands between contain remnants of a faulted and tilted Tertiary section that structurally overlie the metamorphic rocks along poorly exposed, shallow-dipping detachment faults. Upper plate
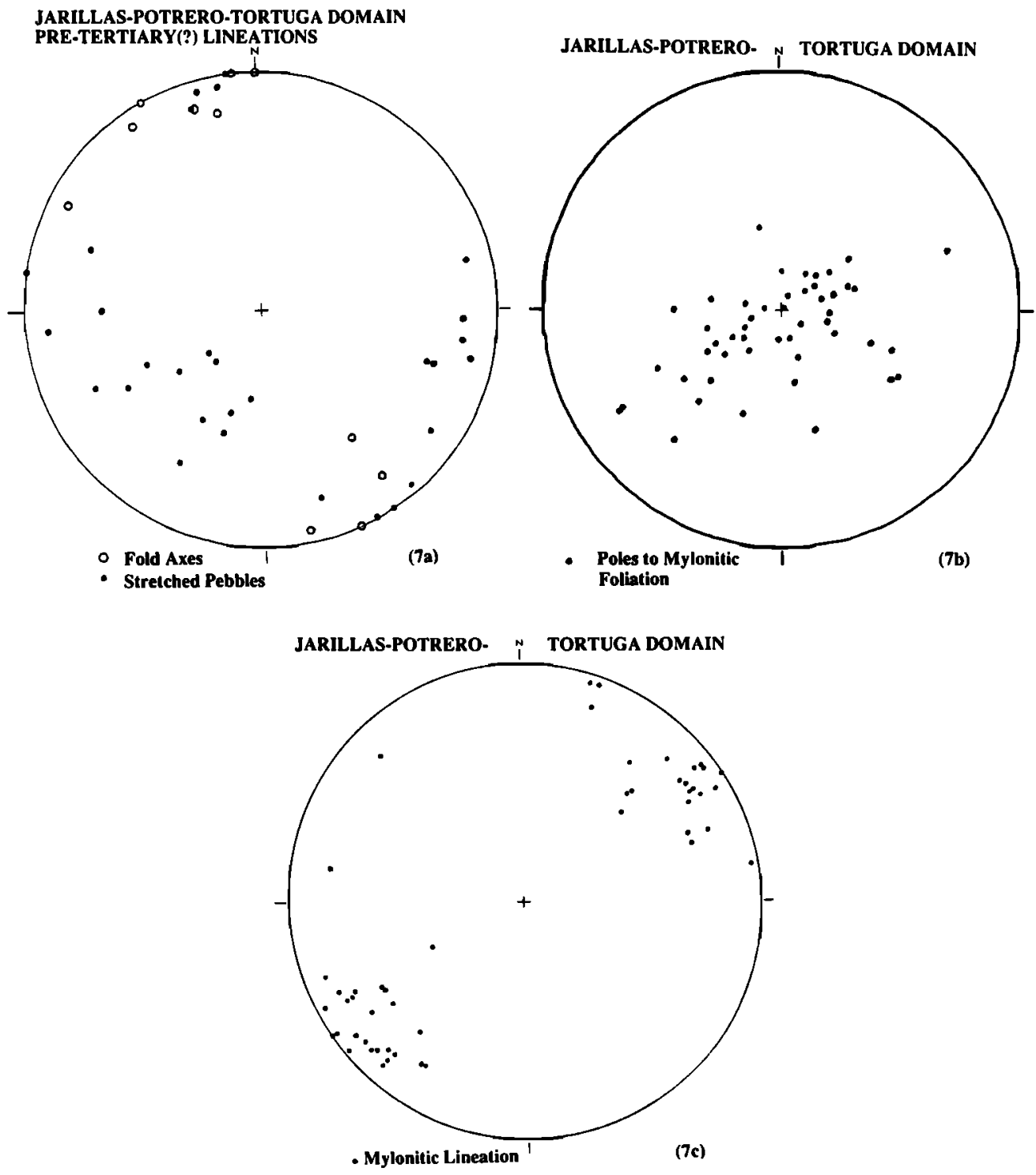

Figure 7. Lower hemisphere equal-area projections of structural elements from the Jarillas-PotreroTortuga domain; (a) pre-middle Tertiary crystalloblastic lineation marked by stretched pebbles and isoclinal fold axes, (b) poles to middle Tertiary mylonitic foliation, and (c) middle Tertiary mylonitic lineation. 
rocks of the Tubutama region are composed of volcaniclastic conglomerate, sandstone, argillite, lacustrine limestone, and borate, with intercalated early Miocene latite [Frye, 1975; Gomez-Caballero et al., 1981; Carillo, 1985].

Northwest of Route 64, Tertiary mylonitic rocks have been studied in two areas. Several north trending hills on strike with Sierra Santa Teresa are underlain by amphibolitic and biotite schist, intruded by 5- to 30-meter thick sills of mylonitized leucocratic granite. Surrounding lowlands are underlain by upper plate strata. North of here, a detachment fault between mylonitized two-mica granite and Tertiary volcanic cover is well exposed along the flank of Sierra del Mezquital.

Tertiary ductile structures in the Tubutama-Mezquital domain are characterized by shallow-dipping foliation with northeasttrending stretching lineation (Figures $8 \mathrm{a}$ and $8 \mathrm{~b}$ ). Seven oriented samples of mylonitic granite and schist from various parts of the domain were studied in thin section, all yielding microstructures with a consistent southwest sense of shear. Northeastward, Tertiary ductile fabric is not prominent, and crystalline rocks preserve an older fabric or no fabric. Near Saric, metamorposed Jurassic supracrustral rocks exhibit welldeveloped foliation and lineation with abundant stretched pebbles and fold hinges, but the overall fabric is poorly oriented (Figure 8c). Some combination of Late Jurassic and Laramide deformation is suspected in this area, but the relationships are uncertain.

\section{Pozo Verde}

The Pozo Verde domain includes Tertiary mylonites exposed in Sierra Pozo Verde, near the border town of Sasabe. Lithologic, structural, and age relationships in this metamorphic core complex are described in detail by Goodwin and Haxel [1990]. We include part of their map in Figure 3. Structural measurements of mylonitic foliation and lineation provided by Haxel [unpublished data, 1981] (Figure 9) are
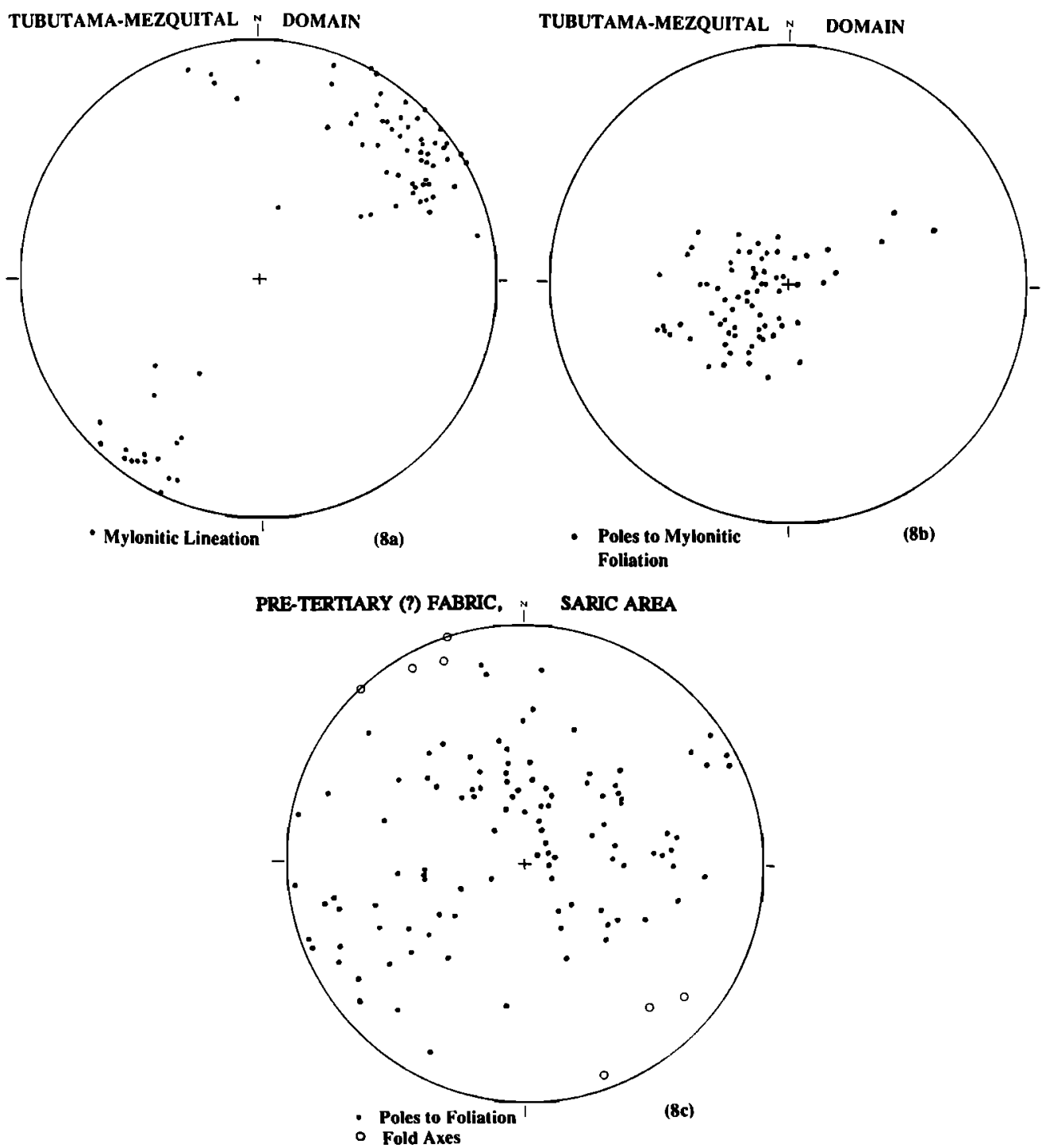

Figure 8. Lower hemisphere equal-area projections of structural elements from the Tubutama-Mezquital domain; (a) middle Tertiary mylonitic lineation, (b) poles to mylonitic foliation, and (c) pre-middle Tertiary crystalloblastic lineation marked by stretched pebbles and fold axes. 

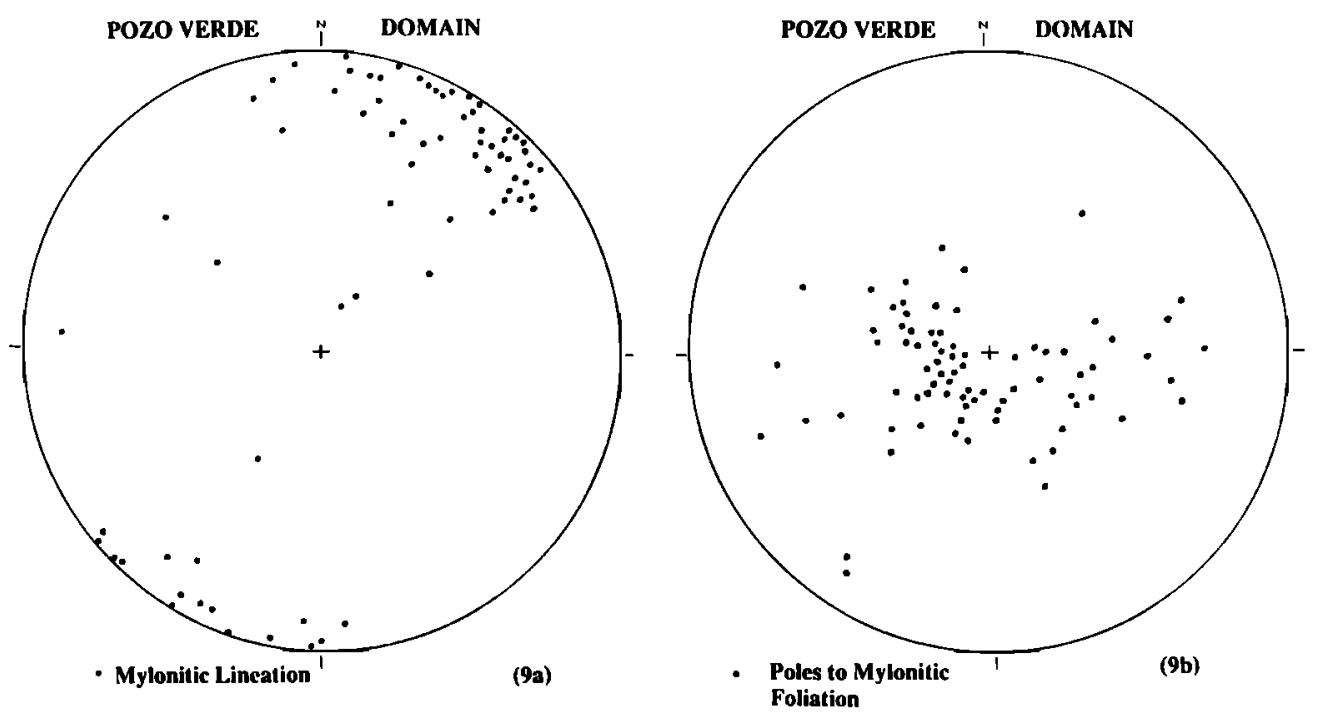

Figure 9. Lower hemisphere equal-area projections of middle Tertiary fabric elements from the Pozo Verde domain (data provided by G. Haxel, personal communication, 1981); (a) mylonitic lineation and (b) poles to mylonitic foliation.

consistent with data from farther north of the same region published by Davis [1980] and Goodwin and Haxel [1990].

Mylonites of the area are derived primarily from the peraluminous granite of Presumido Peak, believed to be early Tertiary in age based on lithologic similarities to the Paleocene granite of the Coyote Mountains [Haxel et al., 1984]. Mylonitic foliation is folded into a broad northnorthwest trending arch. Associated stretching lineations vary from $\mathrm{N} 30^{\circ} \mathrm{E}$ in the south to $\mathrm{N} 10^{\circ} \mathrm{E}$ in the north [Goodwin and Haxel, 1990]. A detachment fault bounds the mylonites on the south and southwest. Middle Tertiary volcanic and sedimentary strata are exposed discontinuously above this surface. Intensity of mylonitic fabric diminishes gradationally about $5-8 \mathrm{~km}$ northeast of the detachment fault, where a mylonitic front coincides with a northwest trending swarm of microdiorite and rhyolite dikes [see Goodwin and Haxel, 1990, Figure 2]. These dikes (approximately $24 \mathrm{Ma}$ ) discordantly intrude all ductile fabric present in the granite [Goodwin and Haxel, 1990]. Thus, mylonitic deformation in the lower plate predates $24 \mathrm{Ma}$, and probably occurred during detachment of slightly older middle Tertiary strata.

Geologic relationships in the Pozo Verde domain are strikingly similar to those in the Magdalena-Madera domain (compare Goodwin and Haxel [1990] with Nourse [1990]). In both regions, early Tertiary two-mica granites intrude preextensional ductile fabrics developed in Jurassic strata. Noncoaxial ductile shear zones superimposed on the granites verge southwest in both cases, and the age of mylonitic deformation is constrained to middle Tertiary. Finally, swarms of northwest trending mafic dikes that crosscut this Tertiary fabric mark the position of a mylonitic front in both areas.

\section{Carnero}

The Camero domain consists of three separate groups of hills situated near the trace of the Mojave-Sonora megashear southeast of Altar. The characteristic tectonostratigraphic element exposed at Cerro Carnero is a weakly to moderately foliated, porphyritic biotite granodiorite that is moderately to strongly lineated [Jacques-Ayala et al., 1990]. This pluton intrudes clastic sediments that include pale green sandstone and pebble-cobble conglomerate with very well-rounded clasts of quartzite and light-colored volcanic rocks. To the north, highway cuts reveal exposures of "Altar schist" composed of gray to purple phyllitic sandstone and siltstone, transitional to calcareous sandstone, with lenses of sandy carbonate, brown mudstone, and granule conglomerate. These strongly deformed fine-grained rocks lie structurally beneath the coarser clastic sequence of Cerro Carnero. Our data (Figure 10) reveal that both clastic units are folded about hinges which trend generally $\mathrm{N} 45^{\circ} \mathrm{W}$ and plunge about $30^{\circ} \mathrm{SE}$. Axial planar cleavage has been locally developed. Smeared and stretched minerals define a lineation which commonly trends $\mathrm{N} 65^{\circ} \mathrm{E}$ to

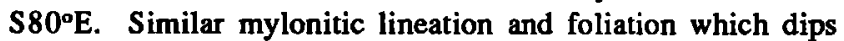
$20^{\circ} \mathrm{NE}$ have been imposed upon the porphyritic granodiorite. Penetrative, subhorizontal $\mathrm{C}$ planes in the granodiorite indicate west directed shear.

In the southern part of Cerro Prieto, which lies about $20 \mathrm{~km}$ south, just south of the megashear, dioritic rocks underlie a resistant cap of dolomite and quartzite. At and near the contact between the igneous and sedimentary units the rocks are intensely sheared. Slickensides are abundant in the diorite on faces plated with talc. Lineated phyllonite is common. The overlying sediments are fractured and strongly cleaved and record kinks as well as small open folds. Highly recrystallized quartzite, carbonate, and coarse mafic pods locally form rods that trend $\mathrm{N} 60^{\circ} \mathrm{E}$.

Farther to the east, north of the megashear, a sinuous band of Cretaceous(?) strata composed of alternating grayish-purple tuffaceous mudstone and light brown or gray quartzofeldspathic sandstone and conglomerate with clasts of mudstone extends to Route 2, where strata are exposed in road cuts. Lineation

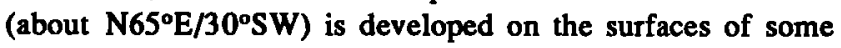

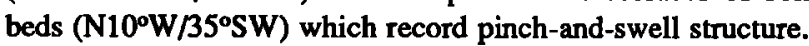




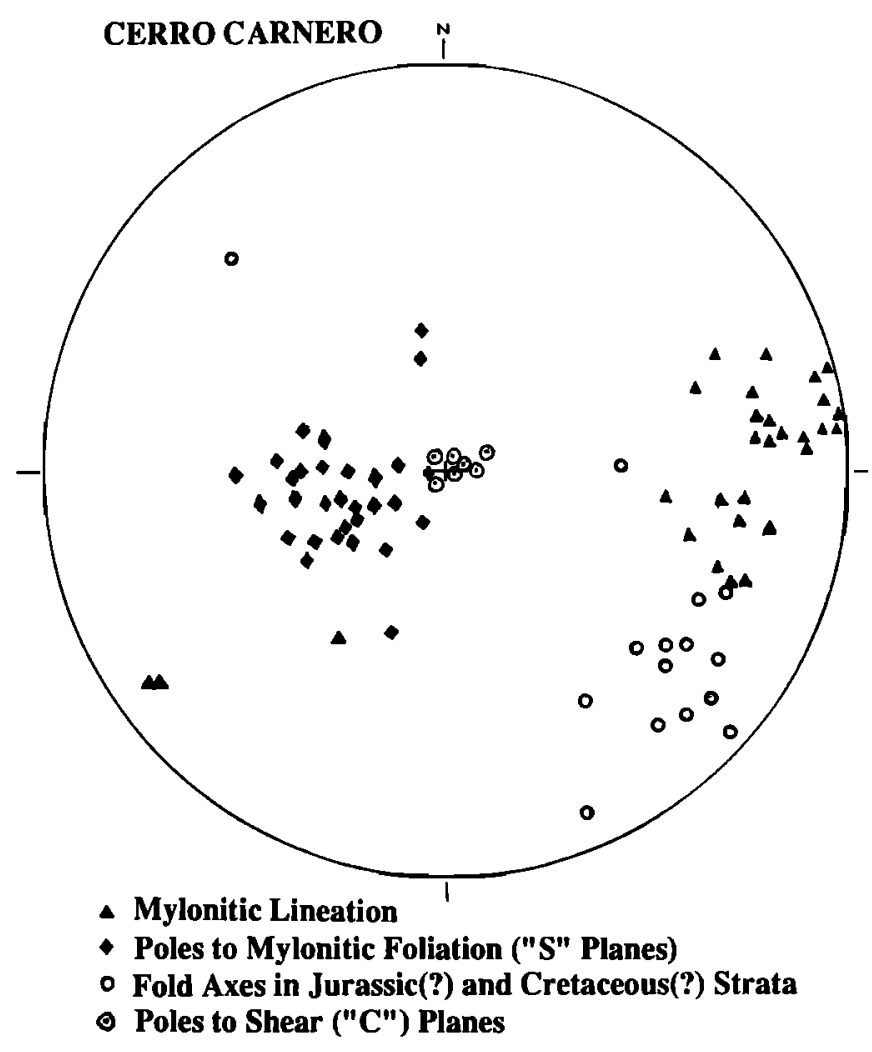

Figure 10. Lower hemisphere equal-area projections of structural elements from the Carnero domain.

\section{Core Complexes Developed in the Caborca Block}

\section{General Character and Boundaries}

In central Sonora, southwest of the megashear, Tertiary mylonitic rocks are not conspicuous in the region immediately south of Caborca where surface exposures of autochthonous Mid-Proterozoic basement and Upper Proterozoic-Paleozoic cover are prominent. However, well-developed mylonitic fabrics are observed in three places farther southeast along the margins of a Paleogene batholith [Anderson et al., 1980] (Figure 11). In contrast to core complexes in the southern Papago block, these mylonites are not associated with extensive areas of regional metamorphism. Instead, they appear to be best developed in areas near the batholith margins. Precambrian, Paleozoic, and Mesozoic rocks composing the roof rocks of the batholith commonly are bounded by low-angle faults and generally preserve structures indicative of shallow crustal deformation [RodriguezCastaneda, 1986; Amaya-Martinez et al., 1988]. The details of prebatholithic deformation have yet to be worked out in this region; and the distinction between Laramide, Late Jurassic, and possibly older structures remains controversial.

\section{Aconchi}

Between the Rios San Miguel de Horcasitas and Sonora is an elongate, northwest trending block, delineated by normal faults (Figure 11). Much of this block is composed of plutonic rocks of the Aconchi and Jaralito batholiths [Chavez, 1978;
Roldan-Quintana, 1991]. Peraluminous two-mica granite from the northem Aconchi batholith has yielded K-Ar ages between 36 and 32 Ma (Table 1). West of Huepac, a northeast dipping detachment fault juxtaposes this granite with upper plate early Miocene sedimentary and volcanic rocks of the Baucurit Formation [Roldan-Quintana, 1979]. Locally developed mylonitic foliation and $\mathrm{N} 60^{\circ} \mathrm{E}$ lineation in the granite are consistent with an inferred northeast transport direction [J. Roldan-Quintana, personal communication, 1993).

North and west of the Aconchi detachment fault, the Aconchi batholith intrudes Precambrian, Paleozoic, and Mesozoic rocks, commonly imbricated along shallow-dipping shear zones [Rodriguez-Castaneda, 1986; Amaya-Martinez et al., 1988]. These prebatholithic structures may exhibit a brittle overprint related to middle Tertiary extension. Younger, steep faults and fractures with northwest trends are conspicuous throughout the northern Aconchi batholith [Chavez, 1978] and its Tertiary volcanic and sedimentary cover [RoldanQuintana, 1979].

\section{Puerto del Sol}

At Puerto del Sol, in the canyon cut by Rio Sonora, weak foliation is developed in a $57 \pm 2 \mathrm{Ma}$ granite [Anderson et al., 1980]. Stronger mylonitic fabrics are observed in float blocks of similar granite along the highway to the west. North of Puerto del Sol, at el Jaralito mine, pendants of marble, quartzite, hornfels, schist, and metaconglomerate share a common east-northeast trending lineation with their host granite [Peabody, 1979] (Figure 12). Ductile fabrics in this area are cut by three distinct sets of planar brittle structures [Peabody, 1979] including (1) late stage pegmatite dikes emplaced along northwest trending fractures which dip southwest, (2) northwest trending, northeast dipping faults and fractures that cut the pegmatite-filled cracks and are themselves filled by mafic dikes, and (3) northwest striking, northeast dipping faults that displace the mafic dikes. No detachment faults or upper plate rocks have been recognized in the vicinity of the Puerto del Sol mylonite domain.

\section{Mazatan}

Sierra Mazatan is a distinctive, crudely circular mountain that lies within a region of somewhat less prominent north trending ranges and basins. The flanks of the mountain rise abruptly from the desert floor, however, its profile is smooth and rounded relative to adjacent ranges (Figure 13). Although isolated from the main mass of the Aconchi batholith to the north, Sierra Mazatan contains similar Paleocene granites [Anderson et al., 1980]. The range marks the southernmost known occurrence of Tertiary mylonite in Sonora (Figures 1 and 11).

The physiographic circular symmetry of Sierra Mazatan belies some structural and stratigraphic asymmetries (Figure 14). Stratigraphic units that compose the main mass of Sierra Mazatan do not define annular patterns. From west to east, crudely north trending belts are characterized by remnants of Paleozoic sedimentary rocks that rest structurally upon mylonitic schists and gneisses, which pass transitionally into less and less deformed granitic rocks.

The westem margin of Sierra Mazatan is distinguished by resistant knobs of Paleozoic beds that jut above the desert 


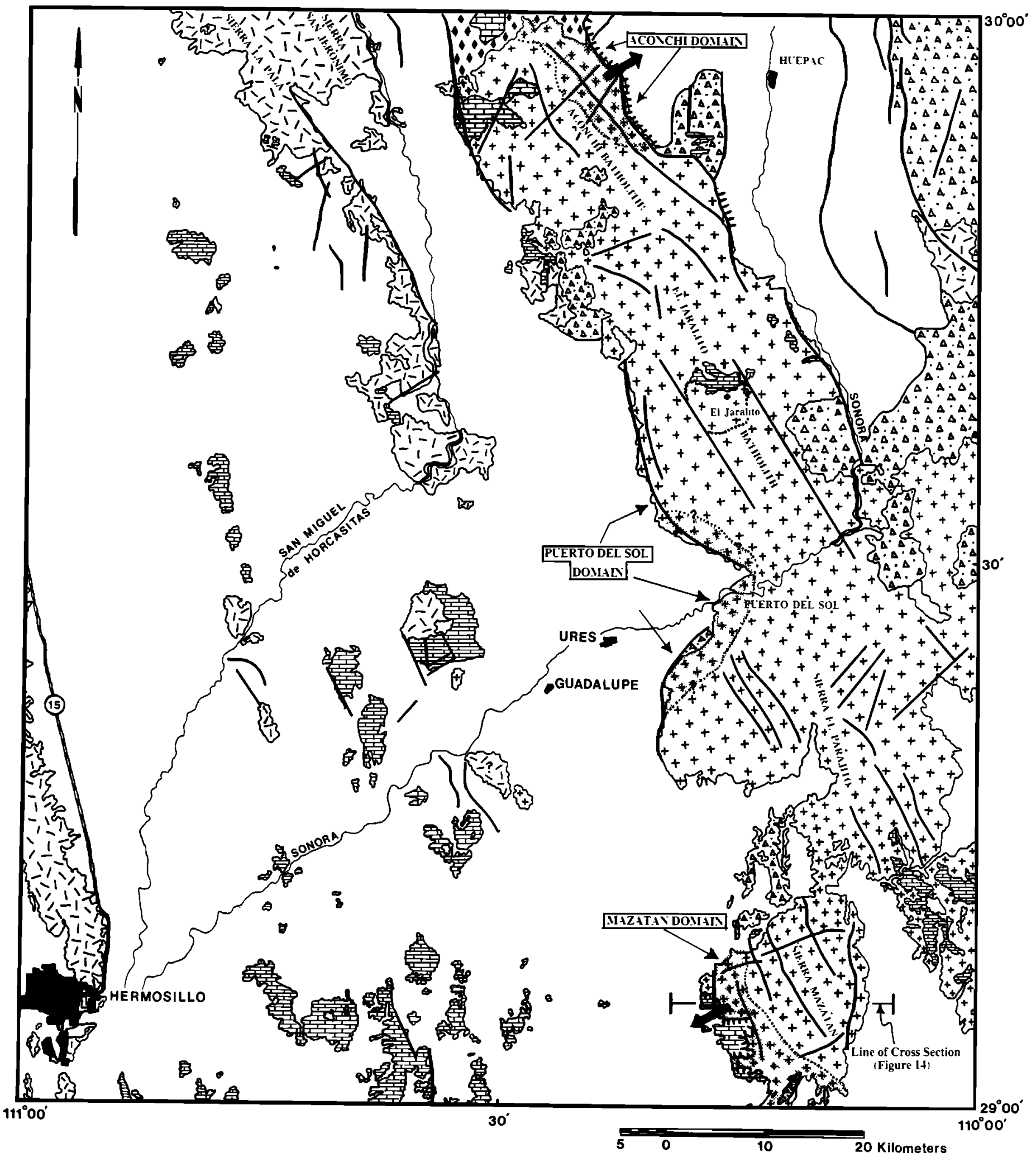

Flgure 11. Geologic map showing core complexes developed in the Caborca block. Patterns for rock units are the same as those in Figure 3, except for the blank pattern, which here includes the early-middle Miocene Baucurit Formation. Solid black arrows infer direction of upper plate detachment. Structural data from the Puerto del Sol and Mazatan mylonite domains are presented in Figures 12 and 15, respectively. 
floor (Figure 13). These strata have not been studied in detail but may represent part of a pre-Tertiary thrust sheet hypothesized by Stewart et al. [1984]. The Paleozoic stratigraphy in nearby areas is generally composed of Ordovician through Pennsylvanian siliceous carbonates

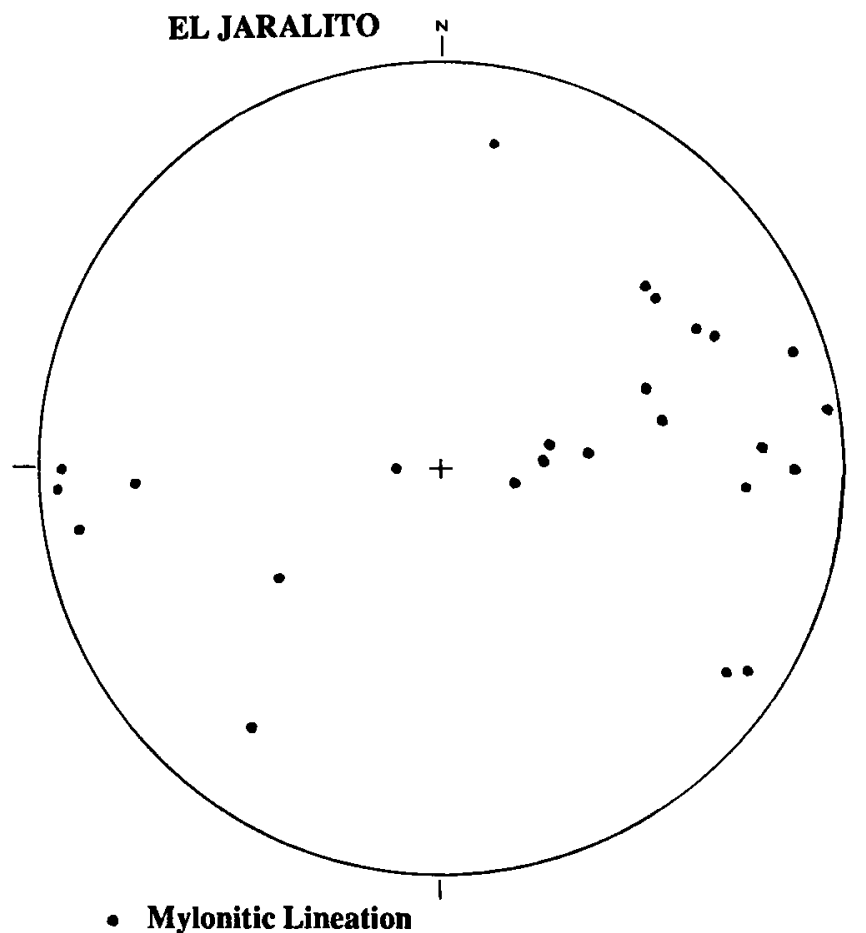

Figure 12. Lower hemisphere equal-area projection of middle Tertiary mylonitic lineation from the el Jaralito mine area (Puerto del Sol domain). overlain by resistant Permian limestone [Poole et al.,1983]. Strata composing the resistant beds at Mazatan are not strongly metamorphosed, nor are they recognized to be folded. Near the mouth of Canada el Bachan the knobs rest on a brittle fault surface, lineated by striae that plunge gently about $\mathrm{S} 60^{\circ} \mathrm{W}$.

Beneath the striated surface that defines the structural base of the Paleozoic sedimentary units lies an array of mylonitic gneisses and schists. The rocks are characterized by subhorizontal foliation and ENE trending lineation (Figure 15). The mylonite zone is composed mainly of light gray granite gneiss with bands of dark gray mafic schist and ultramylonite. Tabular and lenticular sheets of these lithologies may be meters or centimeters thick. In some places, finely banded gneiss is prominent. Masses of interlayered schist and siliceous-micaceous paragneiss are commonly observed to be isoclinally folded (Figure 16). Dikes and sills of leucocratic granite and pegmatite pervade these main lithologies. Boudinage is ubiquitous, and attendant stretching, attenuation, and mylonitization have transposed most preexisting tectonic and intrusive structures. Locally, open folds with hinges parallel to the stretching lineation are observed. The variable degree of shearing, rotation, boudinage, and folding exhibited by the leucogranites indicates that components of that intrusive suite may be either prekinematic or synkinematic with respect to the mylonitization event.

Road cuts through low knolls adjacent to the granitic uplands expose Tertiary(?) red beds. These weakly consolidated rocks include interbedded sedimentary breccia, conglomerate, sandstone, and mudstone. Clasts in the conglomerate beds are commonly composed of volcanic rocks. Granitic clasts are less abundant and are unmylonitized, and carbonate detritus is rare. Faults and shear zones, some of which trend

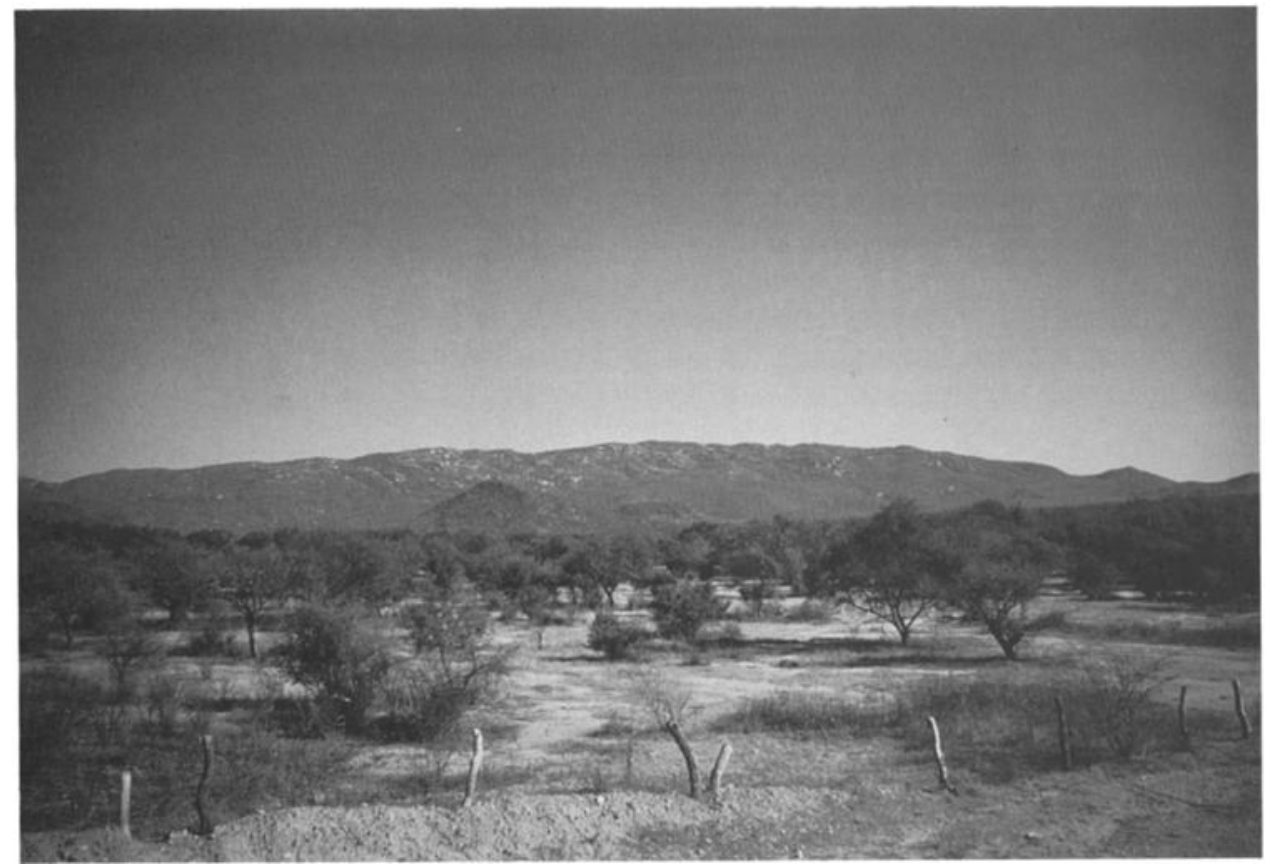

Figure 13. Photograph showing perspective view of the Sierra Mazatan detachment fault viewed from the west; Cerro La Poza in the foreground. 


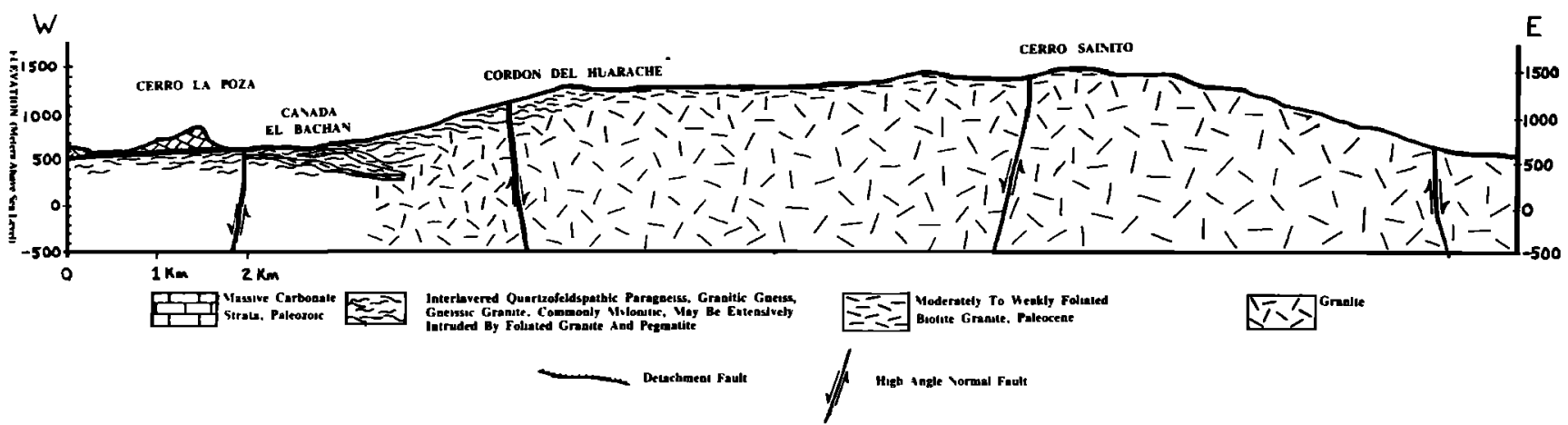

Figure 14. Cross section through the Mazatan core complex. Refer to Figure 11 for location.

northwesterly, cut the strata which are typically tilted with dips as great as $60^{\circ}$ (Figure 15). Some clasts are slightly elongate, and mudstone layers may display a weak, incipient spaced cleavage. At the foot of the western flank of the range, outcrops of poorly indurated volcaniclastic and volcanic beds do not reveal consistent orientations. The relationship of these rocks to the Paleozoic beds resting upon the detachment surface has not been established.

\section{Discussion}

Throughout Sonora, middle Tertiary ductile deformation strongly resembles that of Cordilleran metamorphic core complexes. As in most Cordilleran complexes, normal slip mylonite zones are best developed near the margins of Tertiary granites which may be derived in part from midcrustal melts. Sonoran core complexes are unevenly distributed areally within the northern and central parts of the state. We contend that this uneven distribution reflects compositional differences in the Sonoran crust and the location of favorably oriented pre-Tertiary structures. These compositional and mechanical heterogeneities influenced the partitioning of midcrustal extensional strain across the region.

In the southern Papago block, middle Tertiary mylonitic gneiss and schist occur in conspicuous northwest trending domains throughout a Jurassic and Lower Cretaceous supracrustal province where basement outcrops are rare. These core complexes probably involve Precambrian crust, likely broken by northwest trending steep faults across which the Jurassic volcanic arc accumulated. The arc was crudely bisected during Oxfordian time by the Mojave-Sonora megashear, resulting in sinistral juxtaposition of the Caborca block on the southwest side [Anderson and Silver, 1979]. A related family of northwest trending lineaments developed in the southern Papago block and part of the Pinal block at approximately the same time [Titley, 1976; J. A . Nourse, Jurassic-Cretaceous paleogeography of the Magdalena region, Sonora, and its influence on the positioning of Tertiary metamorphic core complexes, submitted to Geological Society of America Special Paper, 1993]. These structures, recognized as far northeast as Tucson, are associated with northwest elongated basins that accumulated fluvial conglomerate,

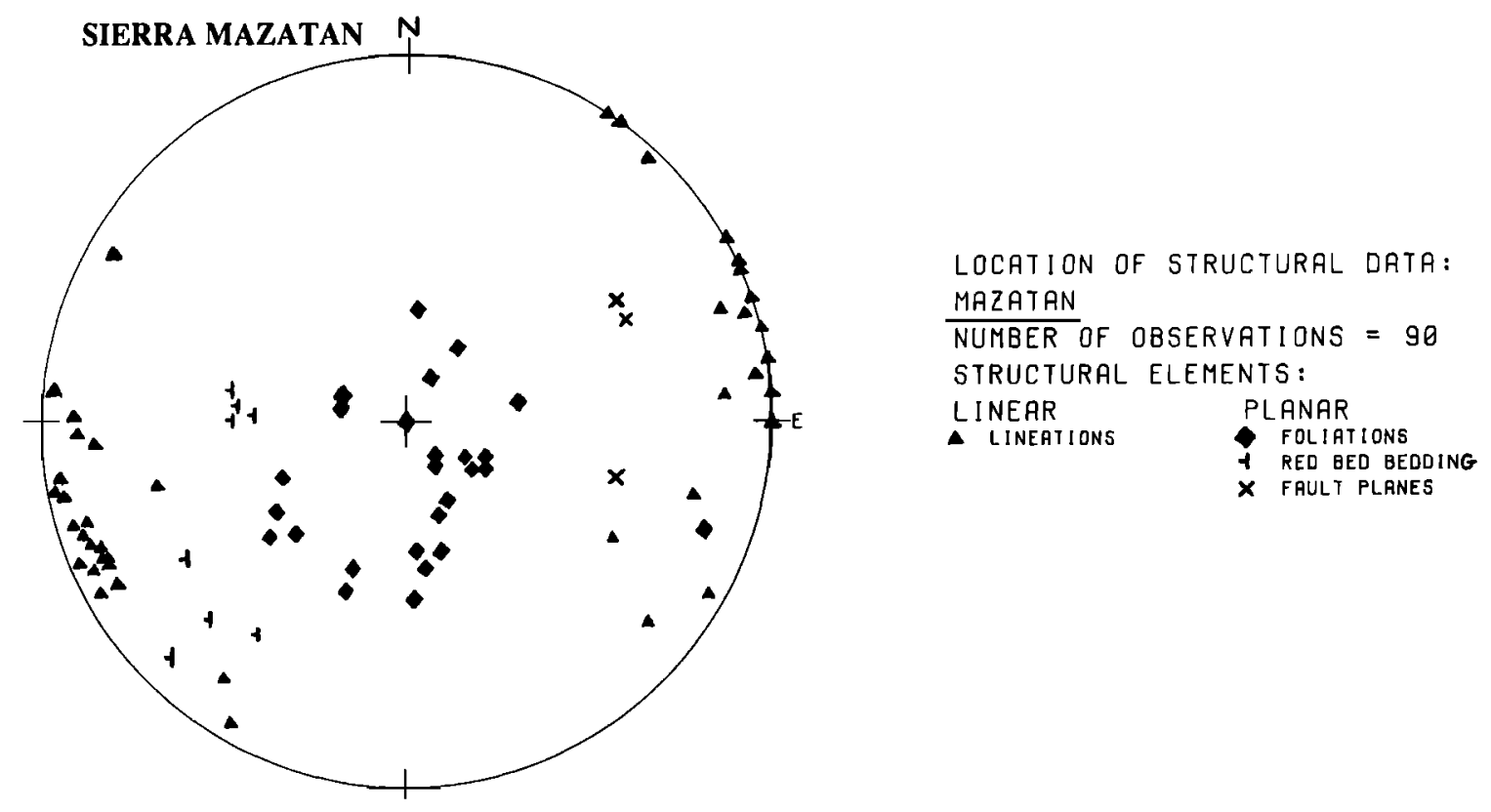

Figure 15. Lower hemisphere equal-area projection of structural elements from the Mazatan domain. 


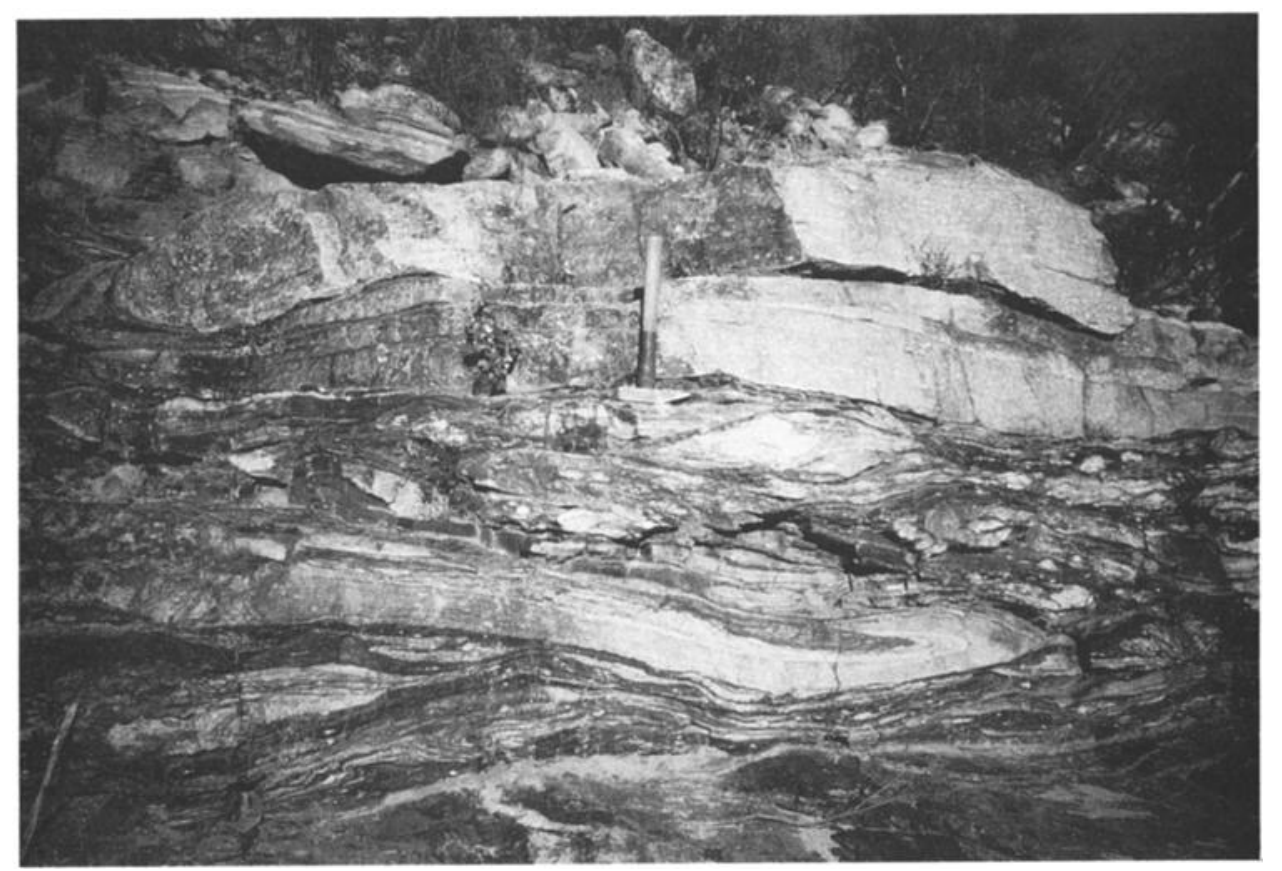

Figure 16. Photograph showing isoclinally folded gneisses within the Mazatan shear zone. View is parallel to mylonitic lineation and foliation.

overlain by siliciclastic marine sediments and carbonates, during Late Jurassic-Early Cretaceous time [Bilodeau et al., 1987; Kitz and Anderson, 1988; Nourse, 1989]. The megashear and a portion of the Jurassic arc southwest of the Imuris lineament later became separate loci for the intrusion of Tertiary granites. Late Oligocene-early Miocene detachment of upper crustal rocks subsequently took place in the directions shown in Figure 3.

In the Caborca block, core complexes are not developed south of Caborca, where generally coherent sections of Precambrian basement and overlying platform strata are exposed. Farther east, however, Tertiary mylonitic fabrics are observed near the margins of Paleogene plutons and within their adjacent country rocks. Shallow crustal structures of preTertiary age, as well as younger detachment faults, are preserved in some upper plate sequences.

The widespread Tertiary ductile fabrics within the southern Papago block are commonly associated with mid-Tertiary peraluminous granite plutons. Greater areal extent of ductile deformation in this region may be attributed to the presence of lower-temperature melting fractions within the Jurassic arc and the existence of wet, quartz-rich Upper Mesozoic sediments northeast of the megashear. Older Cretaceous plutons, intrusive into possibly deeper levels of Precambrian basement were less susceptible to development of ductile structures at their margins.

Core complexes in Sonora began to develop during a widespread middle Tertiary thermal event that culminated with midcrustal shear zone development and upper plate detachment. The timing of mylonitization and detachment faulting is not well enough constrained to deduce any latitudinal age variations between Hermosillo and the international border. Available data indicate that detachment faults throughout most of Sonora were generally active during the same time interval as those in Arizona, Utah, and Nevada (i.e., 25-18 Ma; see Gehrels and Smith [1991], Wright et al. [1986], Dokka et al. [1986], and Lee et al. [1987]. Core complexes of the Pacific Northwest and southern British Columbia record older periods of extension during Paleocene and Eocene time [Parrish, 1984; Harms and Price, 1983]. Younger ages of extension (18-10 Ma) are recorded farther west in the Mojave Desert-Death Valley region [Glazner and Bartley, 1984]. Midcrustal extension at Cerro Carnero may also have taken place later than in the rest of Sonora, if the middle Miocene mica ages from this complex indicate the time of detachment faulting. We suspect that these regional variations in the timing of synextensional magmatism and subsequent detachment faulting may be broadly related to an evolving geometric configuration and thermal state of the subducted Farallon plate during Cenozoic time [Severinghaus and Atwater, 1989].

\section{Conclusions}

Tertiary gneiss and schist with shallow-dipping mylonitic foliations and northeast trending lineations are exposed in many ranges of northern and central Sonora between the latitudes of Hermosillo and the international border. These mylonitic rocks are remnants of midcrustal normal slip shear zones active during middle Tertiary (35-15 Ma) continental extension. Their distribution is systematically associated with regions of crust previously warmed and inflated by Tertiary granitic plutons.

Two crustal blocks affected by Tertiary extension in Sonora display contrasting responses to regional thermal and stress regimes. We believe that these differences may reflect contrasts in pre-Tertiary crustal composition and structure. Northeast of the Mojave-Sonora megashear, regional 
metamorphism and extensional strain are conspicuous and penetrative within Jurassic and Lower Cretaceous rocks which crudely define northwest trending domains. These Mesozoic rocks are postulated to rest upon thinned, weakened, and structurally fragmented basement. Late Jurassic-Early Cretaceous faults may have served as preferential sites for the intrusion of Tertiary granites and the localization of the midcrustal mylonite zones. Southwest of the megashear, core complexes are not known in areas where coherent, autochthonous Precambrian basement is well exposed. Instead, midcrustal extensional mylonites occur along the margins of a Paleogene two-mica granite batholith.

Acknowledgments. The distinct character of the Teniary metamorphic rocks described above was initially recognized by Leon T. Silver, who during a field trip in 1970 noted the similarity in structural style between gneiss in northem Sonora and some of the forerange rocks of the Santa Catalina Mountains near Tucson. The experience and perspicuity of $L$. $T$. Silver and the insight into structural style of George Davis were of crucial importance to T. H. A. and J. A. N. during this research. Anderson benefited from appropriate intellectual bludgeoning conducted by Dick Tosdal and Gordon Haxel during many stimulating. enjoyable, and fruitful exchanges. Discussions with Peter Coney and Doug Shakel were significant. Guillermo Salas, formerly of the Universidad de Sonora, and Jesus Najera and Jaime Roldan of the Instituto de Geologia provided logistical support and helpful advice. Franco Corona assisted during some of the field work. Much research was funded by a National Science Foundation grant EAR 76-84167 awarded to the University of Arizona as part of a cooperative project with George Davis. Gordon Haxel recognized and mapped the detachment fault at Sierra Mezquital during a cooperative field project sponsored by the United States Geological Survey and the Cosejo de Recursos Naturales de Mexico. Anderson also benefited from this program in that considerable structural information was obtained during his part of the mapping. Thesis mapping by J. A. Nourse in the Magdalena-Madera domain and nearby areas was funded in part by two Sigma Xi grants and an NSF grant EAR 8519297 awarded to L. T. Silver. Nourse also gained insight into the geology of Sonora from discussions and field trips with geologists of the Instituto de Geologia. Use of the library and air-conditioned facilities at the Instituto is gratefully acknowledged. Reviews by Jaime Roldan, Steve Reynolds, and an anonomous person substantially improved the original manuscript.

\section{References}

Amaya-Martinez, R., J Bojorquez-Ocho, A. Castro-Rodriguez, M. Figueroa-Valenzuela, A. Grijalva-Haro, S. Morfin-Velarde, and J. Rosas-Haro, Estratigrafia del prospecto Aconchi (abstract), in Resumenes, Segundo Simposio sobre Geoloogia y Mineria de Sonora, edited by E. Almazan-Vasquez and M. Fernandez-Aquirre, p. 3, Universidad Nacional Autonoma de Mexico, Instituto de Geologia Estacion Regional del Noroeste, Hermosillo, 1988.

Anderson, T. H., and L. T. Silver, Late Cretaceous plutonism in Sonora, Mexıco, and its relationship to circum-Pacific magmatism (abstract), Geol. Soc. Am Abstr. Programs, 6, 484, 1974.

Anderson, T. H., and L. T. Silver, U-Pb ages of granitic plutons near Cananea, Sonora, Econ. Geol., 72, 827-836, 1977.

Anderson, T. H., and L. T. Silver, Jurassic magmatısm in Sonora, Mexico (abstract), Geol. Soc. Am. Abstr. Programs, 10, 359. 1978

Anderson, T. H and L. T. Silver, The role of the Mojave-Sonora megashear in the tectonic evolution of northern Sonora, in Geology of Northern Sonora: Field Trip Guldebook for the 1979 annual meeting in San Diego, edited by T. H. Anderson and J. Roldan-Quintana, pp. 59-68, Geological Society of America, Boulder, Colo., 1979.

Anderson, T. H., L. T. Silver, and G. A. Salas, Distribution and $\mathrm{U}-\mathrm{Pb}$ isotope ages of some lineated plutons, northwestern Mexico, in Cordilleran Metamorphic Core Complexes, edited by M. D. Crittenden, Sr., P. J. Coney, and G. H. Davis, Mem. Geol. Soc. Am. 153, 269-283, 1980.

Anderson, T. H., and Silver, L. T., An overview of Precambrian rocks of Sonora, Rev, 5 . 131-139. Univ. Nac. Auto. de Mex., Inst. de Geologia,.Mexico City, 1981.

Anderson, T. H., D. T. Bajek, J. R. Chepega, K M. Ichikawa, J. L. Rodriguez-Castaneda, W. E. Stephens, and L T. Silver, Crystalline thrust sheets near the Mojave-Sonora megashear, Sonora, Mexico (abstract), Geol. Soc. Am. Abstr. Programs, 16, 430, 1984.

Bilodeau, W. L., C. F. Kluth, and L. K. Vedder, Regional stratigraphic, sedimentologic, and tectonic relationships of the Glance Conglomerate in southeastern Arizona, Ariz. Geol. Soc. Dig., 18, 229-256, 1987.

Carillo, R. P, Geologia del area de Tubutama, Sonora, M. S. thesis, 61pp., Univ. Nac. Auto. de Mex., Mexico City, 1985.

Chavez, J. M., Geologie et metallogenie de la Sierra d' Aconchi, Sonora, Mexique, Ph.D thesis, Univ. Pierre et Marie Curie, Paris, 1978.

Cooper, J. R. and L. T. Silver, Geology and mineral deposits of the Dragoon quadrangle, Cochise County, Arizona, U. S. Geol. Surv. Prof. Pap. 416, 96 pp, 1964.

Corona, F., Preliminary reconnaissance geology of Sierra la Gloria and Cerro Basura, northwestern Sonora, Mexico, in Geology of Northern Sonora: Field Trip Guidebook for the 1979 annual meeting in San Diego, edited by T. H. Anderson and J. RoldanQuintana, pp. 32-48, Geological Society of America, Boulder, Colo., 1979.

Crittenden, M. D., Sr., P. J. Coney, and G. H. Davis, (Eds.), Cordilleran Metamorphic Core Complexes, Mem. Geol. Soc. Am. 153, 490 pp., 1980.

Damon, P. E., and R. L. Mauger, Epeirogeny- orogeny viewed from the Basin and Range province, Soc. Min. Eng. AIME, 235, 99112, 1966.

Damon, P. E., M. Shafiqullah, J. RoldanQuintana, and J. J. Cochem, El batolito Laramide (90-40 Ma) de Sonora, paper presented at 14th Convencion Natl. Asoc. Ing. Minas, Metal. Geol. Mex., Guadalajara, Jalisco, Mexico, 1983a.

Damon, P. E., M. Shafiqullah, and K. F. Clarke, Geochronology of porphyry copper deposits and related mineralization of Mexico, Can. Jour. Earth Sci., 20, 1052-1071, 1983b.

Davis, G. H., Structural characteristics of metamorphic core complexes, southern Arizona, in Cordilleran Metamorphic Core Complexes, edited by M D. Crittenden, Sr., P. J. Coney, and G. H. Davis, Mem. Geol. Soc. Am. 153, 35-77, 1980.

Davis, G. H., A. F. Gardulski and T. H. Anderson, Structural-petrological characteristics of some metamorphic core complex terranes in southern Arizona and northern Sonora, in Geology of Northwestern Mexico and Southern Arizona, edited by $\mathrm{L}$. Ortlieb and J. Roldan-Quintana, pp 323-365 , Universidad Nacional Autonoma de Mexico, Instituto de Geologia Estacion Regional del Noroeste, Hermostllo, 1981.

De Jong, K. A., J. A. Escarcega-Escarcega,, and P. E. Damon, Eastward thrusting, southwestward folding, and westward backsliding in Sierra la Vibora, Sonora, Mexico, Geology, 16, 904-907, 1988.

Dokka, R. K., M. J. Mahaffie, and A. W. Snoke, Thermochronologic evidence of major tectonic denudation associated with detachment faulting, northern Ruby 
Mountains, Nevada, Tectonics, 5, 995-1006, 1986.

Eberly, L. D., and T. B. Stanley, Cenozoic stratigraphy and geologic history of southwestern Arizona, Geol. Soc. Am. Bull., $89,921-940,1978$.

Frye, K. L. The geology and mineralization of the Tubutama area, Sonora, Mexico, M. S. thesis, 103 pp., Univ. of Iowa, Iowa City, 1975.

Gehrels, G. E., and C. H. Smith, U-Pb geochronologic constraints on the age of thrusting and peraluminous plutonism in the eastern Rincon Mountains, southern Arizona, Geology, 19, 238-241, 1991.

Gilmont, N. L., Geology of the Puerto la Bandera area, Sonora Mexico, M. S. thesis, 109 pp., Univ. North. Ariz., Flagstaff, 1978.

Glazner, A. F., and J. M. Bartley, Timing and tectonic setting of Tertiary low angle normal faulting and associated magmatism in the southwestern United States, Tectonics, 3, 385-396, 1984.

Gomez-Caballero, A., J. N. Obregon, M. Shafiqullah, M. Arriga, K. Hilario, P. A. Carrillo, and M. Cerecero-Luna, Miocene borax deposit in the Tubutama area, northwest Sonora, Mexico (abstract), Geol. Soc. Am. Abstr. Programs, 13, 58, 1981.

Gonzales-Leon, C., 1980, La formacion Antimonio (Triasico Superior-Jurasico Inferior) en la Sierra del Alamo, Estado de Sonora, Rev. ,4 13-18, Univ. Nac. Auton. de Mex., Inst. de Geol., Mexico City, 1980.

Gonzalez-Leon, C., and C. Jacques-Ayala, La sequencia del Cretacico Temprano del area de Cerro de Oro, Sonora: implicaciones paleogeograficas, (abstract), in Resumenes, Segundo Simposio sobre Geoloogia y Mineria de Sonora, edited by E. AlmazanVasquez and M. Fernandez-Aquirre, pp.2324, Universidad Nacional Autonoma de Mexico, Instituto de Geologia Estacion Regional del Noroeste, Hermosillo, 1988.

Goodwin, L., and Haxel, G., Structural evolution of the southern Baboquivari Mountains, Arizona, Tectonics, 9, 10771095, 1990.

Harms, T. A., and R. A. Price, The Newport fault: Eocene crustal stretching, necking, and listric normal faulting in northeast Washington and northwest Idaho (abstract): Geol. Soc. Am. Abstr. Programs, 15, 309, 1983.

Haxel, G. B., D. J. May, and R. M. Tosdal, Reconnaissance geologic map of the Presumido Peak 15 quadrangle, Arizona, $U$. S. Geol. Surv. Misc. Field Stud. Map MF, 1378, scale 1:62,500, 1982.

Haxel, G. B., R. M. Tosdal, D. J. May, and J. E. Wright, Latest Cretaceous and early Tertiary orogenesis in south-central Arizona: Thrust faulting, regional metamorphism, and granitic plutonism, Geol. Soc. Am. Bull., 95, 631-653, 1984.

Hayama, Y., K. Shibata, and H. Takeda, K-Ar ages of low grade metamorphic rocks in the Altar massif, Sonora, Mexico, Jour. Geol. Soc. Jpn., 90, 589-596, 1984

Jacques-Ayala, C., J. C. Garcia y Barragan, and K. A. De Jong, Caborca-Altar geology: Cretaceous sedimentation and compression, Teriary uplift and extension, in Geologic Excursions through the Sonora Desert Region, Arizona and Sonora, edited by G. E. Gehrels and J. E. Spencer, Spec. Pap. 7, pp. 165-182, Ariz. Geol. Surv., Tucson, 1990 .

Kitz, M. B., and T. H. Anderson, T. H., Deformation and stratigraphy of Lower Cretaceous basinal marine sediments, northcentral Sonora, Mexico, (abstract), in Resumenes, Segundo Simposio sobre Geoloogia y Mineria de Sonora, edited by E. Almazan-Vasquez and $M$. FernandezAquirre, p. 34, Universidad Nacional Autonoma de Mexico, Instituto de Geologia Estacion Regional del Noroeste, Hermosillo, 1988.

Lee, J., E. L. Miller, and J. F. Sutter, Ductile strain and metamorphism in an extensional tectonic setting: a case study from the northern Snake Range, Nevada, USA, in Continental Extensional Tectonics, Geol. Soc. Spec. Pub. 28, 267-298, edited by M. P. Coward, J. F. Dewey, and P. L. Hancock, London, 1987.

Miranda-Gasca, M., and K. A. De Jong, The Magdalena mid-Tertiary extensional basin, in Geology and Mineral Resources of the Sierra Madre Occidental, Mexico. Guidebook for the 1992 Field Conference, edited by K. F. Clark, J. RoldanQuintana, and R. H. Schmidt, pp. 377-384, El Paso Geol. Soc., El Paso, Tex., 1992.

Montano, M., Bosquejo geologico del cuadrangulo "Estacion Llano-Imuris," Bol. 1 (1), pp. 25-49, Dep. Geol. Univ. de Sonora, Sonora, Mex., 1984.

Nourse, J. A., Geological evolution of two crustal scale shear zones, II: The Magdalena metamorphic core complex , Ph.D thesis, pp. 64-396, Cal. Inst. of Technol., Pasadena, 1989.

Nourse, J. A., Tectonostratigraphic evolution and strain history of the Magdalena metamorphic core complex, northern Sonora, Mexico, in Geologic Excursions through the Sonora Desert Region, Arizona and Sonora, edited by G. E. Gehrels and J. E. Spencer, Spec. Pap. 7, pp.155-164, Ariz. Geol. Surv., Tucson, 1990.

Parrish, R., Slocan Lake Fault: A low angle fault zone bounding the Valhalla gneiss complex, Nelson map area, southern British Columbia, in Current Research, Part A, Pap. Geol. Surv. Can., 84-1A, 323-330, 1984.

Peabody, C. E., Geology and petrology of a tungston scarn, el Jaralito, Baviacora, Sonora, Mexico, M. S. thesis, 90 p., Stanford Univ., Stanford, Calif. 1979.

Poole, F. G., B. L. Murchey, and J. H. Stewart, Bedded barite deposits of Middle and Late
Paleozoic age in central Sonora, Mexico (abstract): Geol. Soc. Am. Abstr. Programs, 15, 299, 1983.

Reynolds, S. J., M. Shafiqullah, P. E. Damon, and E. De Witt, Early Miocene mylonitization and detachment faulting, South Mountains, central Arizona, Geology, 14, 283-286, 1986

Reynolds, S. J., S. M. Richard, G. B. Haxel, R M. Tosdal, and S. E. Laubach, Geologic setting of Mesozoic and Cenozoic metamorphism in Arizona, in Rubey Volume 7. Metamorphism and Crustal Evolution of the Western United States, edited by W. G. Ernst, pp. 466-501, Prentice-Hall, Englewood Cliffs, N. J., 1988.

Rodriguez-Castaneda, J. L. Interpretacion del contacto jurasico-cretacico en Sonora estecentral, in Nuevas Aportaciones a la Geologia de Sonora, pp. 37-48, 69-91, Universidad Nacional Autonoma de Mexico, Instituto de Geologia Estacion Regional del Noroeste, Hermosillo, Sonora, 1986.

Roldan-Quintana, J., Geologia y yacimientos minerales del distrito de San Felipe, Sonora, Rev., 3, pp. 97-115, Univ. Nac. Auton. de Mex., Inst. de Geol., Mexico City, 1979.

Roldan-Quintana, J., Geology and chemical composition of the Jaralito and Aconchi batholiths in east-central Sonora, Mexico, Geol. Soc. Am. Spec. Pap. 254, 69-80, 1991.

Salas, G. A., Areal geology and petrology of the igneous rocks of the Santa Ana region, northwest Sonora, Bol. Soc. Geol. Mex., 31, 11-63, 1968.

Severinghaus, J., and T. Atwater, Cenozoic geometry and thermal condition of the subducting slabs beneath western North America, in Basin and Range Extensional Tectonics near the Latitude of Las Vegas, edited by B. Wernicke, Mem. Geol. Soc. Am., 176, 1-24, 1989.

Shafiqullah, M., P. E. Damon, D. J. Lynch, S. J. Reynolds, W. A. Rehrig, and R. H. Raymond, K-Ar geochronolgy and geologic history of southwestern Arizona and adjacent areas, in Studies in Western Arizona, edited by J. P. Jenny and C. Stone, Ariz. Geol. Soc. Dig., 12, 201-260, 1980.

Shakel, D. W., L. T. Silver, and P. E. Damon, Observations on the history of the gneissic core complex, Santa Catalina Mountains, southern Arizona (abstract), Geol. Soc. Am. Abstr. Programs, 9, 1169-1170, 1977.

Silver, L. T., and T. H. Anderson, Possible leftlateral early to middle Mesozoic truncation of the southwestern North American craton (abstract), Geol. Soc. Am., Abstr. Programs, $6,955,1974$.

Silver, L. T., and T. H. Anderson, Evidence for a major Eocene crustal reactivation episode in northern Sonora, Mexico (abstract), Geol. Soc. Am. Abstr. Programs, 16, .656, 1984.

Silver, L. T., and Chappell, B. W., The Peninsular Ranges batholith: An insight into the evolution of the Cordilleran batholiths of 
southwestern North America, Trans. $R$. Soc. Edinburgh Earth Sci., 79, 105-121, 1988.

Stewart, J. H., M. A. McMenamin. and J. M. Morales-Ramirez, Upper Proterozoic and Cambrian rocks in the Caborca region, Sonora, Mexico: Physical stratigraphy, biostratigraphy, paleocurrent studies, and regional relations, U. S. Geol. Surv Prof. Pap. 1309, 36 pp., 1984.

Taliaferro, N. L., An occurrence of Upper Cretaceous sediments in northern Sonora, Mexico, J. Geol., 4l, 12-37, 1933.

Titley, S. R., Evidence for a Mesozoic linear tectonic pattern in southeastern Arizona, Ariz. Geol. Soc. Dig., 10, 71-101, 1976.

Tosdal, R. M., G. B. Haxel, and J. E. Wright, Jurassic geology of the Sonoran desert region, southern Arizona, southeastern
California, and northernmost Sonora: Construction of a continental-margin magmatic arc, in Geological Evolution of Arizona, edited by J. P. Jenny. and S. J. Reynolds, Ariz. Geol. Soc. Dig., 17, 397-434, 1988.

Valentine, W, G, Geology of the Cananea Mountains, Sonora, Mexico, Geol. Soc. Am. Bull., 47, 53-86, 1936.

Wright, J. E., G. B. Haxel, D. May, and R. M. Tosdal, Early Jurassic U-Pb ages for Mesozoic supracrustal sequences in the Papago Indian Reservation, Arizona (abstract), Geol. Soc. Am. Abstr. Programs, 13, 115, 1981.

Wright, J. E., J. L. Anderson, and G. A. Davis, Timing of plutonism, mylonitization, and decompression in a metamorphic core complex, Whipple Mountains, California (abstract), Geol. Soc. Am. Abstr. Programs, 18, 201, 1986.

T. H. Anderson, Department of Geology and Planetary Sciences, University of Pittsburgh, Pittsburgh, PA 15260.

J. A. Nourse, Department of Geological Sciences, California State Polytechnic University, Pomona, CA 91768.

L. T. Silver, Division of Earth and Planetary Sciences, California Institute of Technology, Pasadena, CA 91125.

(Received April 15, 1993; revised November 16, 1993; accepted November 26, 1993) 